\title{
Electric Power Transmission for a Hanford Nuclear Energy Center (HNEC)
}

H. Harty

W. J. Dowis, Consultant

June 1983

Prepared for

UNC Nuclear Industries

under Related Service Agreement

with the U.S. Department of Energy

under Contract DE-AC06-76RLO 1830

Pacific Northwest Laboratory

Operated for the U.S. Department of Energy

by Battelle Memorial Institute 


\title{
DISCLAIMER
}

This report was prepared as an account of work sponsored by an agency of the United States Government. Neither the United States Government nor any agency thereof, nor any of their employees, makes any warranty, express or implied, or assumes any legal liability or responsibility for the accuracy, completeness, or usefulness of any information, apparatus, product, or process disclosed, or represents that its use would not infringe privately owned rights. Reference herein to any specific commercial product, process, or service by trade name, trademark, manufacturer, or otherwise, does not necessarily constitute or imply its endorsement, recommendation, or favoring by the United States Government or any agency thereof. The views and opinions of authors expressed herein do not necessarily state or reflect those of the United States Government or any agency thereof.

\author{
PACIFIC NORTHWEST LABORATORY \\ operated by \\ BATTELLE \\ for the \\ UNITED STATES DEPARTMENT OF ENERGY \\ under Contract DE-AC06-76RLO 1830
}

\begin{tabular}{|c|c|}
\hline \multicolumn{2}{|c|}{ Printed in the United States of America } \\
\hline \multicolumn{2}{|c|}{ Available from } \\
\hline \multirow{3}{*}{\multicolumn{2}{|c|}{$\begin{array}{l}\text { National Technical Information Service } \\
\text { United States Department of Commerce } \\
5285 \text { Port Royal Road } \\
\text { Springfield, Virginia } 22161\end{array}$}} \\
\hline & \\
\hline & \\
\hline \multicolumn{2}{|c|}{$\begin{array}{l}\text { NTIS Price Codes } \\
\text { Micrafiche A01 }\end{array}$} \\
\hline \multicolumn{2}{|c|}{ Printed Copy } \\
\hline & Price \\
\hline Pages & Codes \\
\hline $001-025$ & $\mathrm{~A} 02$ \\
\hline $026-050$ & $\mathrm{~A} 03$ \\
\hline $051-075$ & A04 \\
\hline $076-100$ & A05 \\
\hline $107-125$ & A06 \\
\hline $126-150$ & $A 07$ \\
\hline $151-175$ & $A 08$ \\
\hline $176-200$ & A09 \\
\hline $201-225$ & $\mathrm{~A} 010$ \\
\hline $226-250$ & $A 011$ \\
\hline $251-275$ & A012 \\
\hline $276-300$ & $\mathrm{~A} 013$ \\
\hline
\end{tabular}




\section{0}

ELECTRIC POWER TRANSMISSION FOR A HANFORD NUCLEAR ENERGY CENTER (HNEC)

H. Harty

W.J. Dowis, Consultant

June 1983

Prepared for UNC Nuclear Industries under a Related Services Agreement with the U.S. Department of Energy under Contract DE-AC06-76RLO 1830

Pacific Northwest Laboratory

Richland, Washington 99352 
.

$\cdot$

- 
CONTENTS

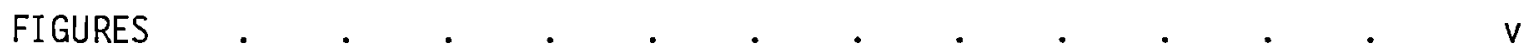

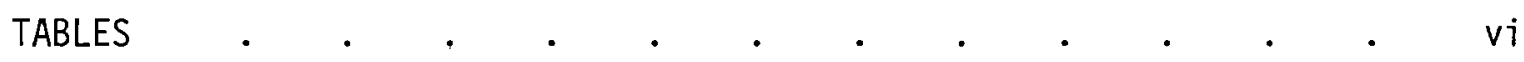

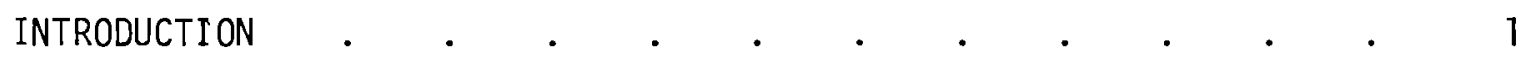

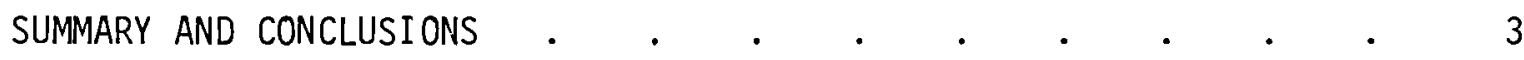

GENERAL APPROACH . $. \quad . \quad$. . . . . . . . . 7

LOAD GROWTH

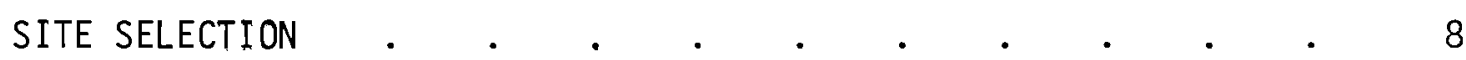

AVAILABILITY OF RIGHTS-OF-WAY . . . . . . . . 10

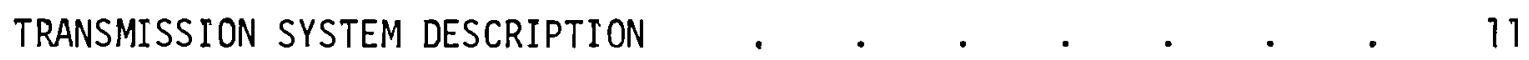

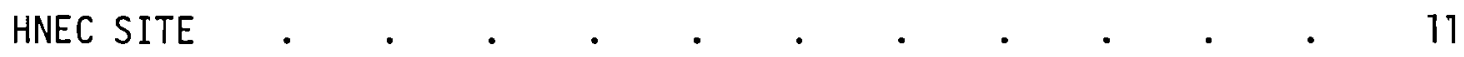

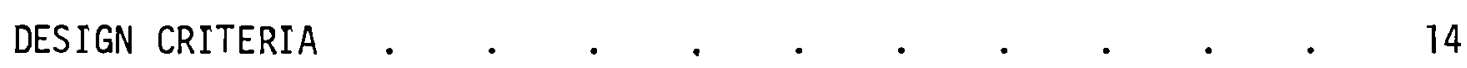

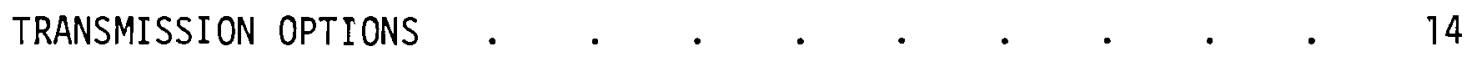

DESCRIPTION OF TRANSMISSION SYSTEM CONCEPTS $\quad . \quad \ldots \quad$ • $\quad$ • 15

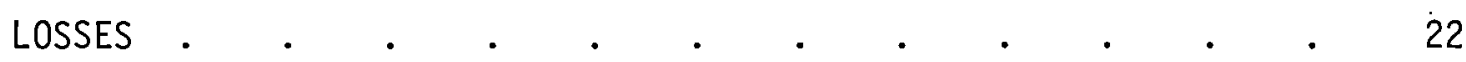

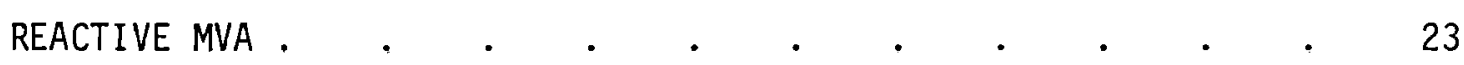

TERMINAL SWITCHING ARRANGEMENTS . . . . . . . . . 23

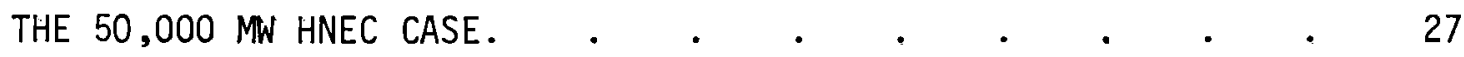

ECONOMICS . . . . . . . . . . . . . . . 29

ECONOMIC GROUND RULES .

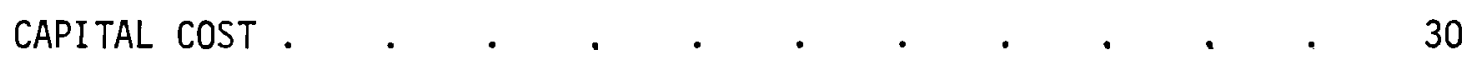

OPERATING AND MAINTENANCE COSTS . . . . . . . . . . . 32

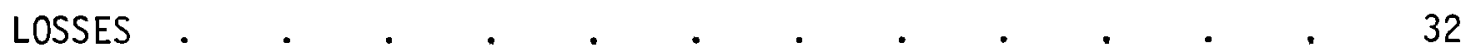

SUMMARY OF ANNUAL COSTS . . . . . . . . . . . . 32

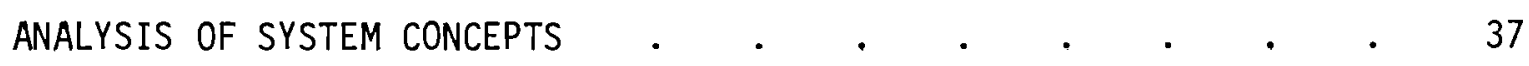

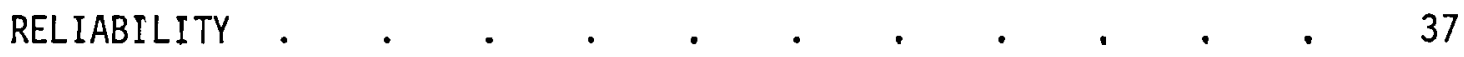

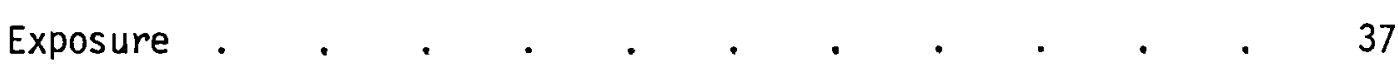




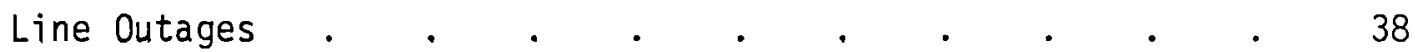

Loss of AlT Lines in a Right-of-Way $\quad . \quad \ldots \quad . \quad . \quad . \quad 39$

Loss of an Entire Switching Station . . . . . . 39

Simultaneous Loss of Two HNEC Switching Stations . . . 41

Failure to Clear High-Current Faults . . . . . 41

Stability. . . . . . . . . . . . . . 42

RESERVES. . . . . . . . . . . . . . . 43

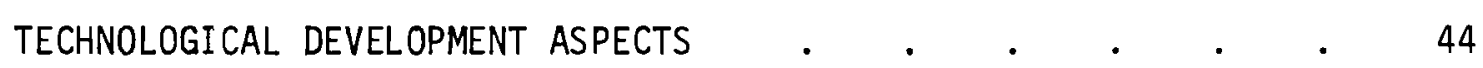

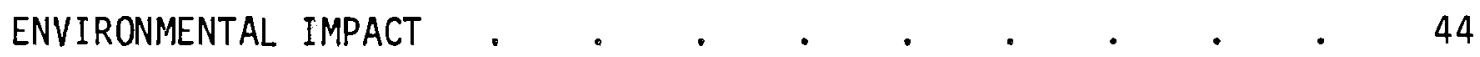

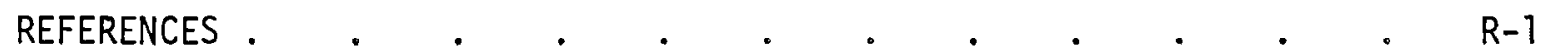

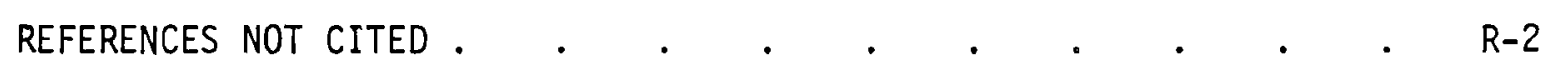

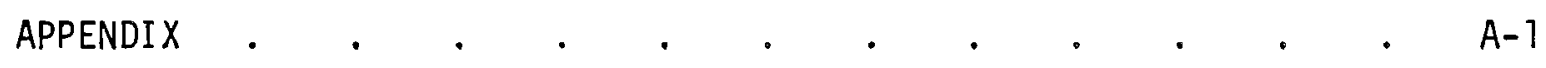




\section{FIGURES}

1 Pacific Northwest Electric Power Planning and Conservation

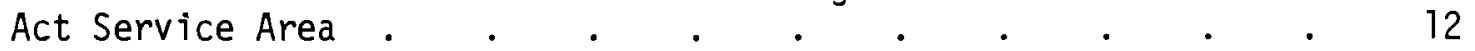

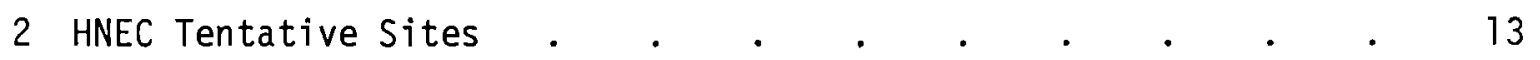

3 Pacific Northwest Transmission System Additions

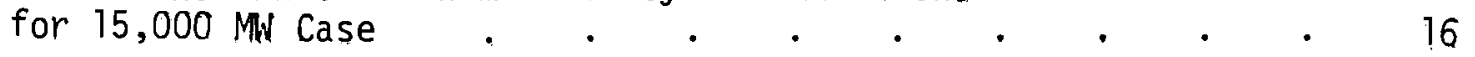

4 Pacific Northwest Transmission System as Planned

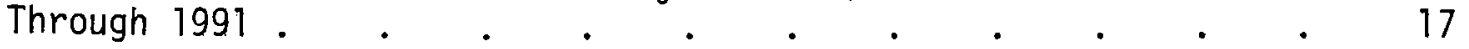

5 Peak Load Power Flows for HNEC 6,000 MW Case . . . . . 18

6 Peak Load Power Flows for HNEC 10,000 MW Case . . . . 19

7 Peak Load Power Flows for HNEC 15,000 MW Case . . . . 20

8 Switching Stations - HNEC 6,000 MW Case $\quad . \quad \ldots \quad . \quad . \quad$. $\quad 24$

9 Switching Stations - HNEC 10,000 MW Case . . . . . . 25

10 Switching Stations - HNEC 15,000 MW Case . . . . . . . 26

EHV-UHV Tower Configuration, Capacity, and
Right-of-Way Requirement . . . . . . . . . . 46 


\section{$\underline{\text { TABLES }}$}

1 Assumed Plant Additions at HNEC in Megawatts . $\quad . \quad$. $\quad . \quad 9$

2 Major Cross-Mountain Additions Beyond $1991 \quad$ • $\quad . \quad$. $\quad$ • $\quad 15$

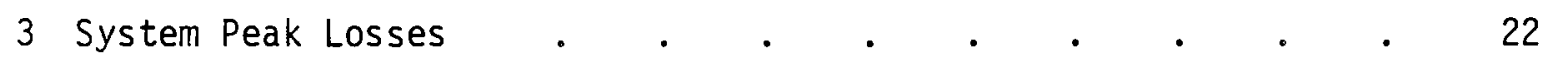

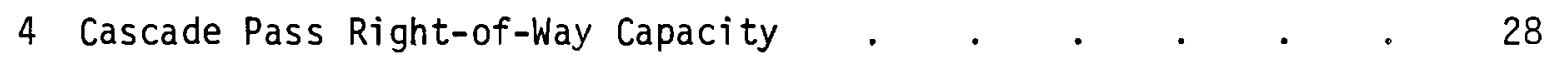

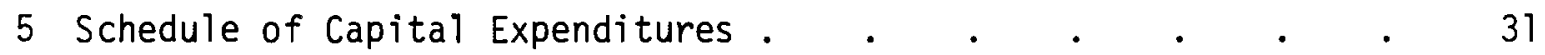

6 Estimated Cost of System Losses . . . . . . . . . . . . 33

7 Total Annual Costs and Energy Transmitted . . . . . . 34

8 Risk of Interruption of $50 \%$ or More of the Power Flow
Through a Switching Station

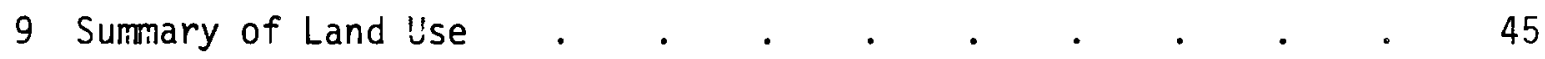

A-1 Cost Estimating Data, $1100 \mathrm{kV}$ Line . . . . . . . A

A-2 Cost Estimating Data, $500 \mathrm{kV}$ Shunt Capacitor . . . . A A-1

A-3 Generic Construction Schedule for Interest
During Construction . . . . . . . . . . . A-2

A-4 Unit Value of Losses . . . . . . . . . . . . A-2 


\section{ACKNOWLEDGMENT}

The data on the transmission system was provided by Bonneville Power Administration. The efforts of Brian Silverstein are particularly appreciated. 


\section{INTRODUCTION}

A study of nuclear energy centers was conducted by the Atomic Energy Commission and reported in WASH 1288, Evaluation of Nuclear Energy Centers, January 1974. The portion of the study covering a Hanford Nuclear Energy Center (HNEC) was conducted by Pacific Vorthwest Laboratory, and a preliminary study of transmission of HNEC power was prepared with the assistance of the Bonneville Power Administration (BPA).

In 1975 the Energy Research and Development Administration (ERDA) requested a more detailed study of the HNEC, one aspect of which focused on the transmission system. The transmission system was developed through a series of technical discussions with BPA personnel responsible for transmission system planning. The purpose of the discussions was to further develop a concept of a system which will transmit power from HNEC to markets in the Pacific Northwest.

The original study of transmission for an HNEC, which was completed in September 1975, was updated in June 1978. The present 1983 revision takes cognizance of recent changes in the electric power situation of the PNW with respect to 1) forecasts of load growth, 2) the feasibility of early use of $1100 \mathrm{kV}$ transmission, and 3) the narrowing opportunities for siting nuclear plants in the region. The purpose of this update is to explore and describe additions to the existing transmission system that would be necessary to accommodate three levels of generation at HNEC. Comparisons with a PNW system having new thermal generating capacity distributed throughout the marketing region are not made as was done in earlier versions.

The planning of a power transmission system is an iterative process developed over a considerable time period. This report is a current iteration, and substantial further studies will be required to firm up a transmission system for an HNEC, should such a generation expansion develop.

For purposes of this study of possible future transmission requirements, the base generating capacity at HNEC in 1993 is set at $5000 \mathrm{MW}$, 
which is assumed to increase to $6000,10,000$, and 15,000 MW, through future capacity additions.

Cursory consideration is given to potential expansion of system capacity to transmit up to $50,000 \mathrm{MW}$ from HNEC should it be required in the more distant future. 


\section{SUMMARY AND CONCLUSIONS}

Approximately $75 \%$ of Pacific Northwest loads are west of the Cascade Range, and are now primarily served by hydroelectric plants east of the Range. In the future, energy will be supplied primarily by thermal plants, with peaking capacity provided by the hydro system and combustion turbines .

In this study a11 unprogrammed generating resources beyond 1993 are assumed to be located at HNEC except for a delayed WNP-5 unit at Satsop. Transmission requirements were determined for three levels of generating capacity at HNEC: $6,000,10,000$, and 15,000 MW. Under different load forecasts the HNEC 15,000 MW level would be reached in the year 2004, 2006, or 2017.

Although the timing of transmission system additions would depend on which load forecast is correct, the nature of the addition would be the same, unless substantial amounts of unprogrammed coal-fired generating capacity were added at sites other than Hanford. Under the study assumptions the total east-to-west peak power flow over the Cascade Range would increase from less than 18,000 MW for the 5,000 MW base to 28,900 MW in the 15,000 MW case. These flows would be accommodated by the present grid supplemented with three major $1100 \mathrm{kV}$ east-west lines and some relatively minor $500 \mathrm{kV}$ line additions.

The major issues examined herein are: 1) type of transmission to be employed and an assessment of its technical feasibility, 2) availability of rights-of-way, 3) economics, 4) environmental impact, and 5) overall reliability of the transmission system.

The type of transmission selected for bulk power transfer from an HNEC for the time period studied is overhead AC, $1100 \mathrm{kV}$, which is now technologically proven.

No extensive underground transmission is contempleted during the period

of this study. Conditions at HNEC terminal switching stations do not require it, and throughout the system no right-of-way contingencies are indicated that would compel any more than localized undergrounding. 
The major transmission system additions for each concept studied are:

\begin{tabular}{ccccc} 
Case & $\begin{array}{c}\text { Number of Cross-Mountain } \\
1100 \mathrm{kV} \text { Transmission Lines }\end{array}$ & & \multicolumn{2}{c}{$\begin{array}{c}\text { Total Length } \\
\mathrm{km}(\mathrm{Mi})\end{array}$} \\
\cline { 2 - 3 } & 1 & & 290 & $(180)$ \\
$10,000 \mathrm{MW}$ & 2 & 590 & $(365)$ \\
$15,000 \mathrm{MW}$ & 3 & 880 & $(545)$
\end{tabular}

There are no plans to replace in-service $500 \mathrm{kV}$ lines with $1100 \mathrm{kV}$ lines. Only lines of $345 \mathrm{kV}$ and below would be retired for replacement by higher-voltage, higher-capacity lines.

Transmission switching station bus arrangements shown in the report would accommodate line terminals and generating units up to the 15,000 MN level in three stations spaced along an 18-mile axis in the Hanford reservation. Power concentration of that level could result in fault currents near the 1 imits of circuit breakers now available. If required, additional development to increase interrupting capacity ratings and reduce clearing times is expected to be accomplished by the time of HNEC need.

Rights-of-way are available across the mountains assuming that present ones can be utilized and widened as necessary in localized areas. By replacing existing $230 \mathrm{kV}$ and $345 \mathrm{kV}$ lines with $1100 \mathrm{kV}$, the transfer capacity of the corridors could be increased up to about $87,000 \mathrm{MW}$. This would accommodate more than 50,000 MW generation at HNEC.

The economics of the case studies are summarized below. The costs are for transmission facilities added after 1992, estimated in constant 1982 dollars. Capital investment required for lines, switching stations, series capacitors, and reactive compensation, is estimated to be:

$\begin{array}{cc}\text { Case } & \text { Investment, \$ Mil1ion } \\ 6,000 \mathrm{MW} & 415 \\ 10,000 \mathrm{MW} & 849 \\ 15,000 \mathrm{MW} & 1282\end{array}$

Transmission cost per kilowatt-hour delivered at load centers, for the increment of HNEC generating capacity considered herein, is estimated 
at about 3 mills. This is about 7 percent of the value of the energy transmitted. Expressed differently, for an increment of 10,000 MW of thermal generating capacity at HNEC, the price of bulk power at the load centers would be expected to be about 7 percent higher than the price at the busbar, due to the costs of transmission. This unit cost is average for all HNEC plants and corresponding system 1oads. Individual HNEC generating plants with output wheeled to specific load centers may have greater or less unit transmission cost.

Environmental factors can be summarized as follows:

- 2767 acres in new rights-of-way required for the 6,000 MW case, 3555 acres for the 10,000 MW case, and 4623 acres for the 15,000 MW case, in agricultural, range, forest, and residential/industrial 1 and.

- More visual intrusion in cross-mountain corridors caused by (1arger) $1100 \mathrm{kV}$ towers replacing $230 \mathrm{kV}$ towers--one additional line for the 6,000 MW case, two additional 1 ines for the 10,000 MW case, and three additional lines for the 15,000 MW case.

System reliability factors can be summarized as follows:

- With respect to internal failures and common hazards, up to and including 1 oss of a 11 lines in a corridor, the HNEC system could be designed to have a reliability essentially equal to that of the existing system.

- Several events, such as tornado, major earthquake, etc., could conceivably destroy one or more of the three switching stations at the HNEC. However, the risk of loss of generation because of switching station failure does not add significantly to the risk of generating plant outage or transmission line failure from the same event.

The heaviest power flows are in the corridor running southwest from HNEC. Reliability effects of interruptions of flow in this and other corridors have been studied, and the results of the studies have been used in developing a transmission system concept for each case which would meet the Western Systems Coordinating Council's (WSCC) and the 
Bonneville Power Administration's reliability criteria. The matter of reliability as affected by disastrous events at HNEC also concerns the generating plants and is factored into those studies.

The conclusions, summarized from the above findings, are:

- Transmission of up to 15,000 MW from HNEC to markets is considered feasible from the standpoints of technology and access to rights-ofway. Technology for $1100 \mathrm{kV}$ transmission should be proven by the mid-1980s.

- Additions to the HNEC transmission system would have some additional environmental impact in land use and visual effects.

- The estimate of transmission cost burden of the HNEC cases (about 3 mills per kilowatt hour) is approximately 7 percent of the estimated cost of bulk power at the generating plant busbar.

- Although overall HNEC system reliability has not been analyzed in detail nor its relative level computed, it appears to be as acceptable as that of the existing system.

- Looking to the more distant future, 50,000 MW generated at HNEC could be transmitted across the Cascade Range, assuming successful development of $1100 \mathrm{kV}$ technology, utilizing available rights-of-way with widening in some places. 


\section{GENERAL APPROACH}

Hydroelectric resources in the Pacific Northwest have been developed to nearly the fullest extent possible, with the exception of potential low-capacity resources at dispersed sites. Future energy load growth, beyond that offset by conservation achieved by consumers, may be served for the most part from large central station thermal plants. One scenario for locating these plants is concentrating new thermal capacity at Hanford.

Transmission facilities and investment, power and energy losses, and land requirements are examined for three stages of development at the Hanford Nuclear Energy Center (HNEC). Assumptions on rate of load growth, site selection, and availability of rights-of-way are defined at the outset of the study.

\section{LOAD GROWTH}

An energy center could serve 1) loads dispersed throughout the region, 2) industrial loads concentrated at HNEC, and 3) loads outside the region. In this study, loads in the two latter categories are ignored, except to the extent that loads at HNEC could affect transmission switching station design. Loads attracted to HNEC, which would not exist in the region otherwise, would affect only HNEC internal transmission requirements. Transmission to loads outside the Northwest is considered only to the extent of presently allowed exchanges over existing tie lines to the Southwest.

The rate of load growth determines the schedule for new generation plants, which in turn dictates transmission system additions. However, once plant site selections are made, the timing of the transmission additions can first be linked to the startup of new thermal plants and then to a load forecast. The impact of changes in load growth rate can then be readily examined,

Load forecasts used by Pacific Northwest utilities for planning have been prepared by the Pacific Northwest Utilities Conference Committee (PNUCC) for over 20 years. This type of forecast is the sum of utilities (SOU) loads, estimated by the region's utilities and by BPA for its Direct 
Service Industrial (DSI) and Federal Agency customers. The total Northwest Region energy loads are forecasted in the May 1982 edition to grow to an average annual rate of $2.7 \%$ over the ten-year period 1983 to 1993 . Load growth beyond 1993 can be extrapolated at the growth rate for the final year, $2 \%$.

Pursuant to the Pacific Northwest Electric Power Planning and Conservation Act of 1982 (Regional Act), the Northwest Power Planning and Conservation Council will develop a Regional forecast to guide BPA's acquisition of major resources. The Council's plan is scheduled to be adopted in April 1983.

As part of its internal planning operations, BPA issued in Apri1 1982 a forecast of loads for the years 1981 to 2000. A baseline forecast and alternative high and low forecasts were developed. Average annual growth rates of $1.6 \%$ and $1.8 \%$ for the first and second ten-year period, respectively, are indicated in the baseline forecast. These rates increase to $2.6 \%$ and $2.3 \%$, respectively, in the high growth forecast.

\section{SITE SELECTION}

Resources planned by the region's utilities through 1993 are outlined in the PNUCC forecast. At the end of this time frame, WNP-2 and WNP-1 are scheduled to be in operation at Hanford, as well as two Skagit units relocated at Hanford. WNP-3 is scheduled to be in operation at Satsop, and additional coal-fired generation at Creston, near Grand Coulee, is also planned.

A11 unprogrammed resources beyond 1993 are assumed to be located at Hanford, except for the delayed WNP-5 unit at Satsop. Table 1 contains schedules of thermal capacity installed at HNEC for three different load growth rates. All units would be of $1300 \mathrm{MW}$ gross capacity, operating at $70 \%$ plant factor.

Both the PNUCC load forecast and the BPA high growth forecast would yield generation deficits in 1993, the last year of scheduled resources. It is assumed in the load-resource balance developed for Table 1 that the deficits are eliminated by unprogrammed resources in 1996. 
TABLE 1. Assumed Plant Additions at HNEC in MW Three Load Forecasts

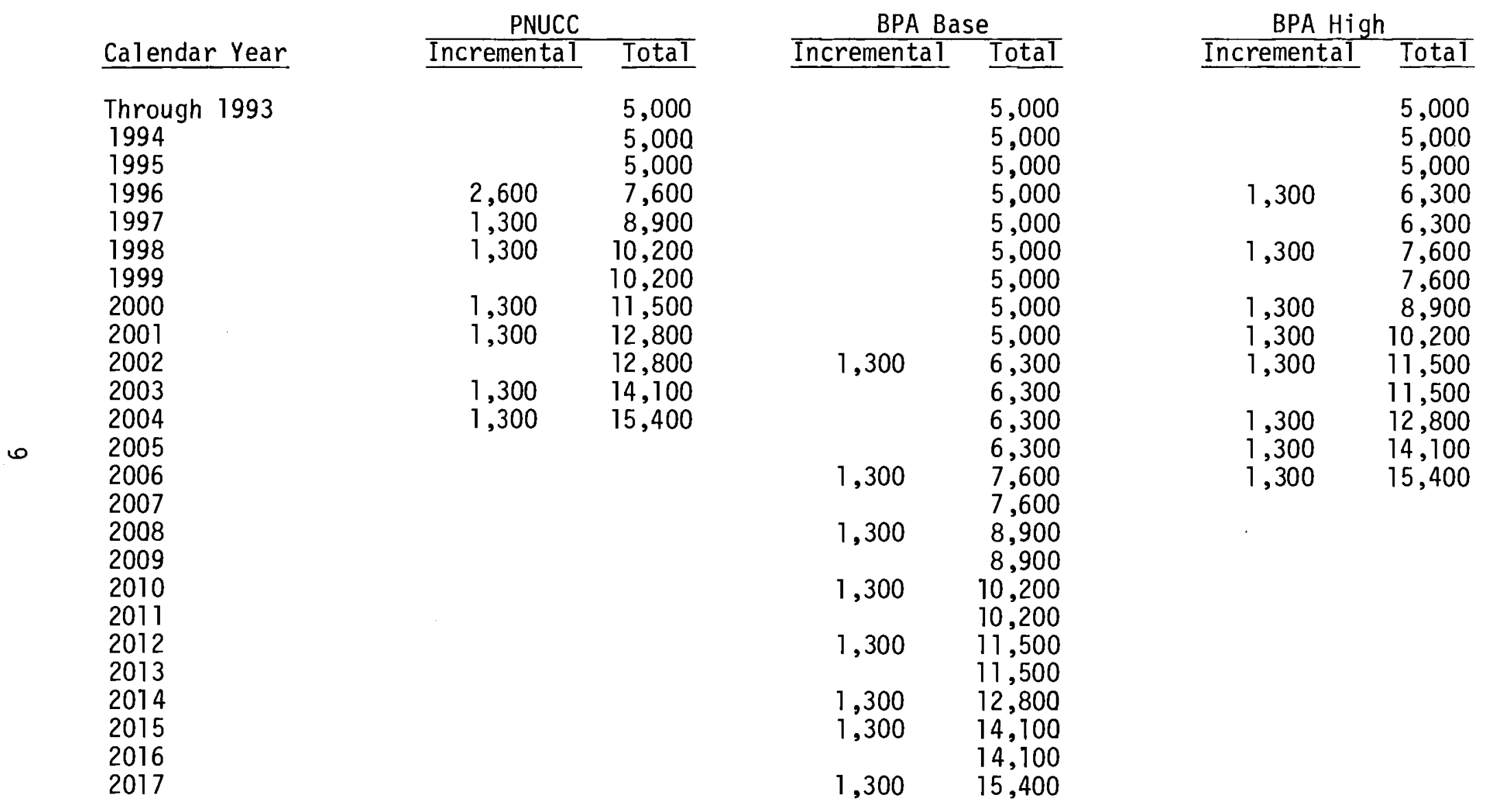


If, instead, load growth follows the BPA base forecast, and plants are energized as planned in the PNUCC schedule, then there will be a generation capacity surplus in 1993. Unprogrammed resources are not added in this scenario until 2002, when the surplus is eliminated by load growth. The treatment of the imbalances in load and resources may affect the timing for the HNEC 6,000 MW case somewhat, but would not have any impact on HNEC $10,000 \mathrm{NW}$ and $15,000 \mathrm{NW}$ cases.

If the trend is toward more use of coal-fired plants at sites other than Hanford, the dates for reaching the designated capacities of HNEC 6,000 MW, 10,000 MW, and 15,000 MW cases would be delayed. Transmission requirements for these cases may change somewhat, depending on the location of the coal-fired generation.

\section{AVAILABILITY OF RIGHTS-OF-WAY}

The power system of the Pacific Northwest may be characterized as having its major generating facilities, now mainly hydroelectric, east of the Cascade mountain range, and its major markets west of the range. Power is transmitted westward and southwestward through seven mountain passes. A concentration of new thermal generating capacity at HNEC would add to the present power flows through the passes. In forming a concept of transmission system to accommodate HNEC power flow, an important goal has been to confine the new lines to existing rights-of-way where possible, particularly in mountain crossings and other scenic areas.

This study assumed that corridors through mountain passes would be limited to those now available, but that these rights-of-way could be slightly widened as necessary. 


\section{TRANSMISSION SYSTEM DESCRIPTION}

The marketing area for power generated at existing plants, and power to be generated in the future in new facilities at HNEC is the Pacific Northwest Region, as defined by the Regional Act. Utilities serving this area are Bonneville Power Administration, Idaho Power Company, Montana Power Company, Pacific Power and Light Company, Portland General Electric Company, Puget Sound Power and Light, Utah Power and Light Company, Washington Water Power Company, and 104 public agency customers of BPA. The area served is shown on the map of Figure 1.

\section{HNEC SITE}

The Hanford reservation covers approximately 570 square miles, part of which is unavailable for thermal plants, it being used for government facilities, arid land ecology studies, and similar purposes.

Tentative sites selected for nuclear plants are shown in circles on the map of Figure 2, and general areas suitable for the construction of, or expansion of, transmission switching stations are shown as squares. Corridors considered suitable for the transmission lines are also shown.

Construction of or planning for two nuclear plants by WPPSS in area No. 1 is in progress, with switching station equipment now installed at the Hanford substation and the Ashe substation. Plans are being formulated to relocate the two Skagit units to a site between Ashe and Hanford. A transmission line right-of-way has been established between the Hanford and Ashe substations, with one $500 \mathrm{kV}$ line currently energized. The transmission to accommodate up to $15,000 \mathrm{MW}$ at HNEC would be expanded from that al ready in place or planned.

As shown in Figure 2, the three substations are separated by distances of approximately 10 and $19 \mathrm{~km}$ ( 6 and $12 \mathrm{miles}$ ) with the end stations being $29 \mathrm{~km}$ (18 miles) apart. Separation of stations is an element in reliability analysis, discussed later in the report. 


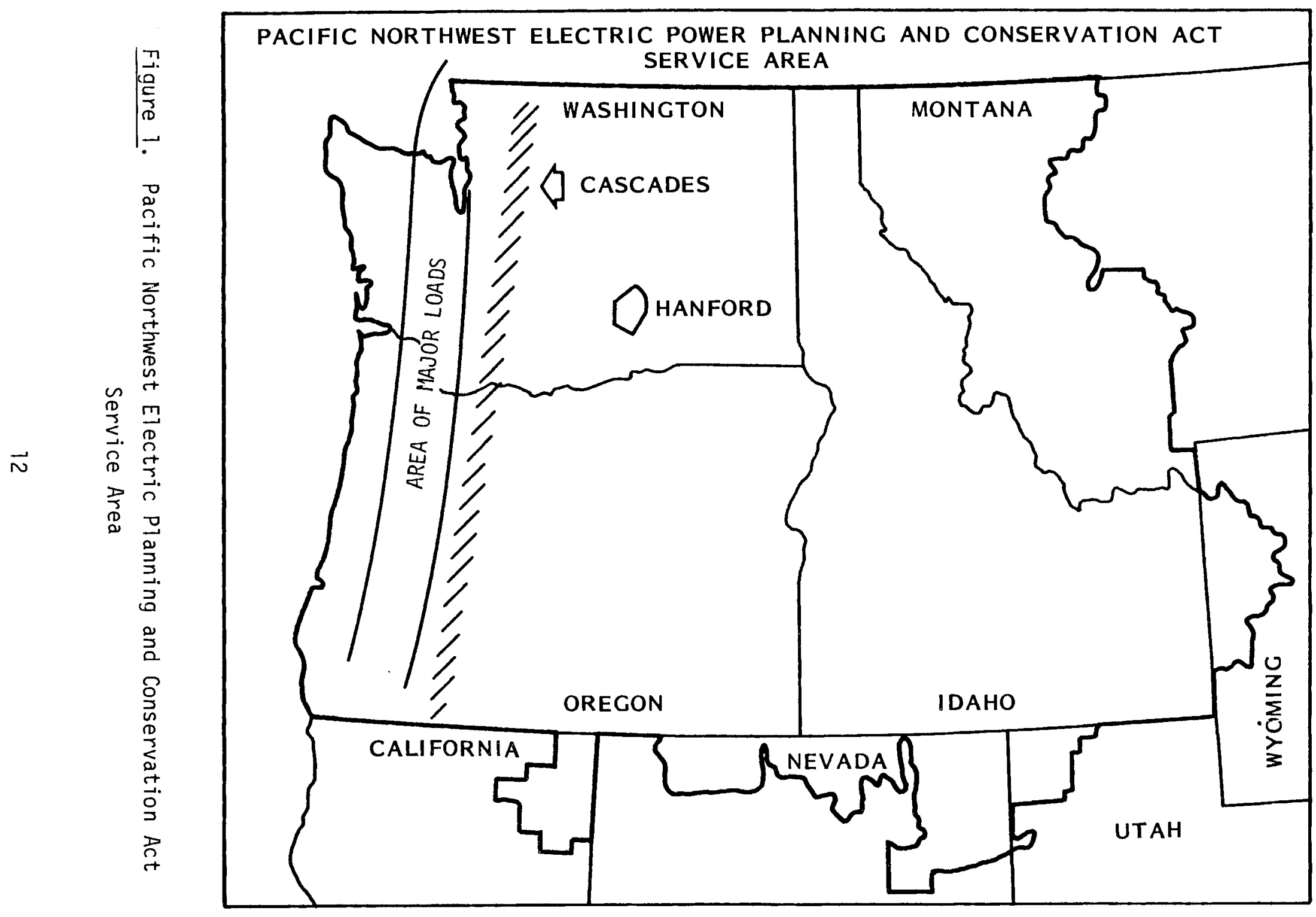




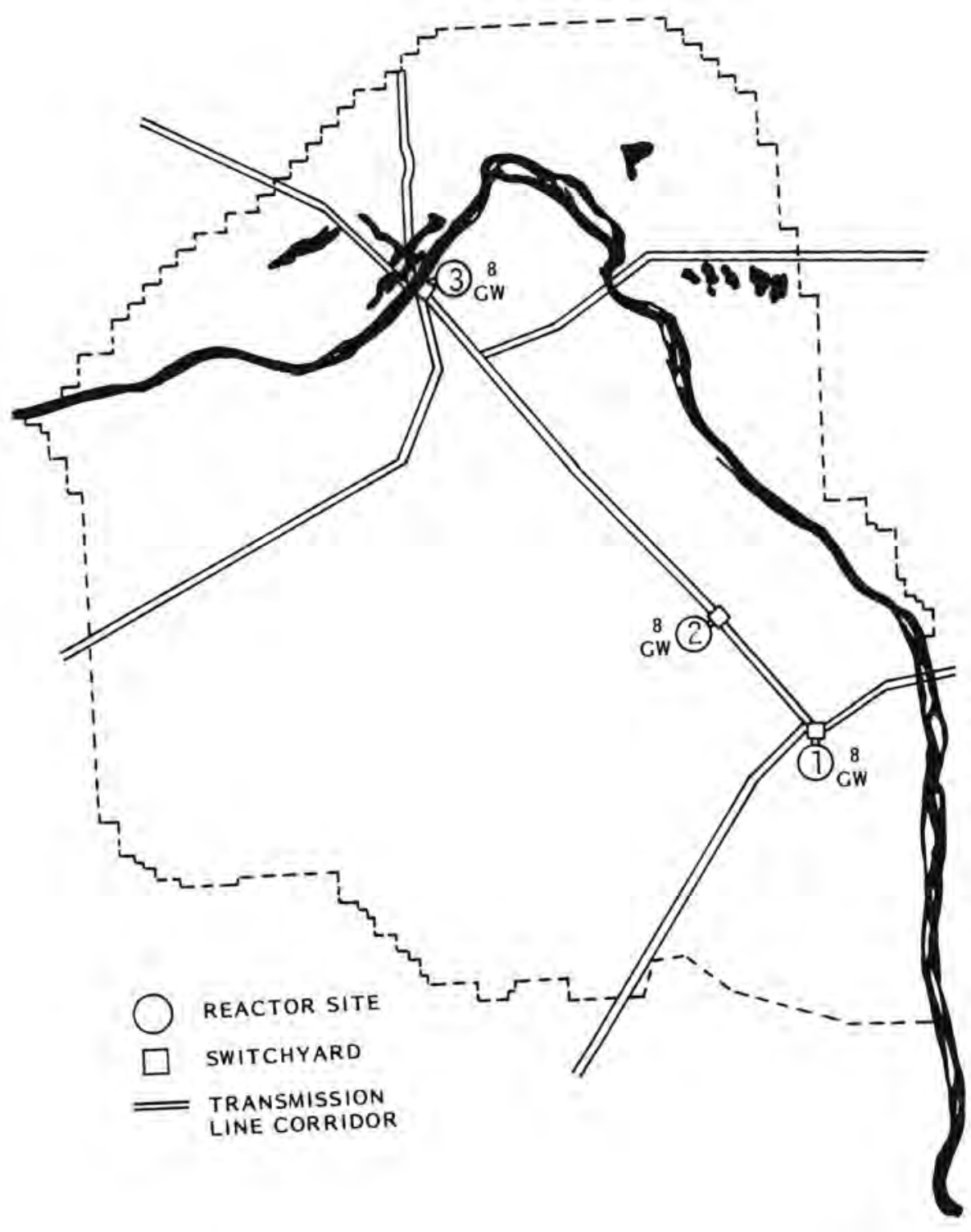

FIGURE 2. HNEC Tentative Sites 
It is assumed that only power plant group sites No. 1 through 3 would be involved through the $15,000 \mathrm{MW}$ 1evel. Other possible locations in the Hanford reservation would be developed only if expansion beyond 15,000 MW in generating capacity were to take place. Each of these general site areas is assumed to accommodate at least six 1300 MW units. Terminal switching arrangements and capacity in outgoing 1 ines are based on these assumptions.

\section{DESIGN CRITERIA}

Criteria used in the planning and design of the transmission system for a11. cases conform to the reliability criteria of the Western Systems Coordinating Counci1 (WSCC) and BPA.

Criteria used to determine the extent, if any, to which underground transmission may be required are:

1) At Hanford, underground transmission would be utilized only if congestion made necessary clearances impractical, or if needed for reliability purposes, i.e., to avoid exposure to common mode failure of multiple major lines.

2) At receiving ends, underground transmission would be used only when rights-of-way for overhead lines would be unavailable, for environmenta 1, zoning, or economic reasons.

\section{TRANSMISSION OPTIONS}

A11 transmission lines in the three cases are of overhead construction. It was assumed that in no case did application of the foregoing criteria require underground transmission. Gas insulated substation (GIS) equipment and buses may be utilized to alleviate congestion and minimize substation land requirements.

Currently, $500 \mathrm{kV}$ is the highest transmission voltage level applied in the Pacific Northwest system. BPA is actively developing and testing $1100 \mathrm{kV}$ transmission lines and substation equipment, with the goa 1 of making $1100 \mathrm{kV}$ available for commercial application in the early 1990s. Advantages in loss savings and maximized use of transmission corridors are offered by $1100 \mathrm{kV}$ 
over double-circuit $500 \mathrm{kV}$, the highest capacity transmission 1 ine currently in use. Therefore, $1100 \mathrm{kV}$ is considered the long-term alternative for bulk power transmission, although BPA is evaluating both options for the next line. In this study, a11 future cross-mountain lines are assumed to be $1100 \mathrm{kV}$, although double-circuit $500 \mathrm{kV}$ could be substituted on a one-for-one basis for the $1100 \mathrm{kV}$ lines during the study period.

\section{DESCRIPTION OF TRANSMISSION SYSTEM CONCEPTS}

The transmission system of the Pacific Northwest, as planned to 1991, is shown in Figure 3. Additions and modifications to this base system to accommodate 15,000 MW at HNEC are 1isted in Table 2 and shown in Figure 4 over the background of the 1991 system.

\section{TABLE 2. Major Cross-Mountain Additions Beyond 1991}

$\begin{array}{lc}\text { In Service } & \text { Length km (mi) } \\ \text { HNEC } 6,000 & 290(180) \\ \text { HNEC } 10,000 & 300(185) \\ \text { HNEC } 15,000 & 290(180)\end{array}$

Description

$\begin{array}{ll}\text { Ashe-Portland Area } & 1100 \mathrm{kV} \\ \text { Grand Coulee-Snoqualmie } & 1100 \mathrm{kV} \\ \text { Gable Mtn-Portland Area } & 1100 \mathrm{kV}\end{array}$

Figure 3 shows only one DC transmission line to the south. A second Tine has been proposed for the 1990s but it is not in the BPA budget. If it is built, the power flow diagrams to be presented herein would be modified somewhat, but the required east-west transmission lines for the three HNEC cases would not be changed. The primary use of the DC lines in the future wil1 be for capacity exchange. At the January PNW peak load, flow would be to, rather than from, the PNW except in years in which there would be considerable excess hydro energy. This circumstance would not significantly change the cross-mountain transmission requirements.

Power flows in major transmission corridors are shown (Figures 5 and 7) under January peak load conditions for three levels of development at HNEC.

In addition to the major cross-mountain lines 1 isted in Table 2, other sections of 1 ines will be needed to augment local system capacity. For the period beyond 1991, the following facilities would be required: 


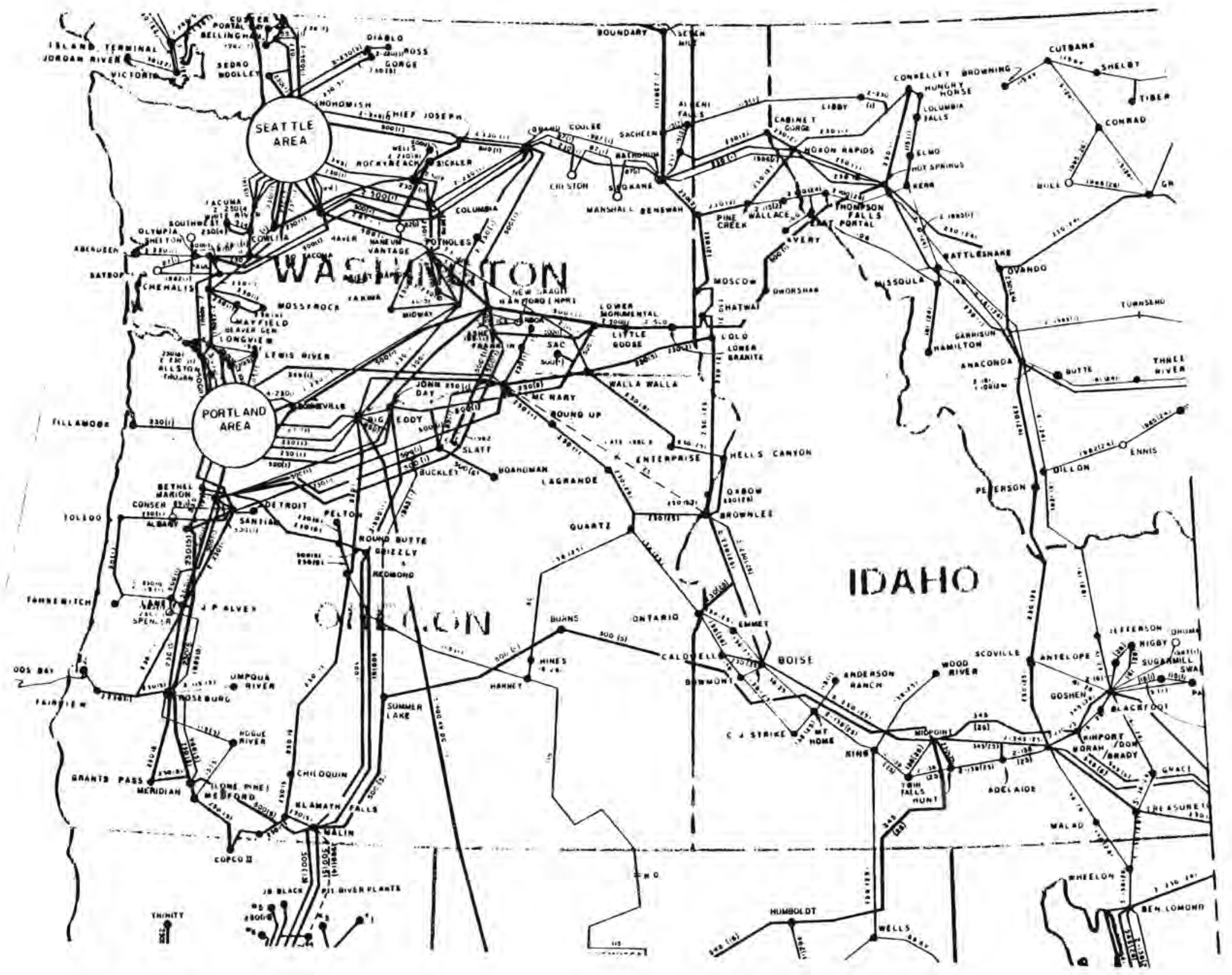

FIGURE 3. Pacific Northwest Transmission System as Planned Through 1991. 


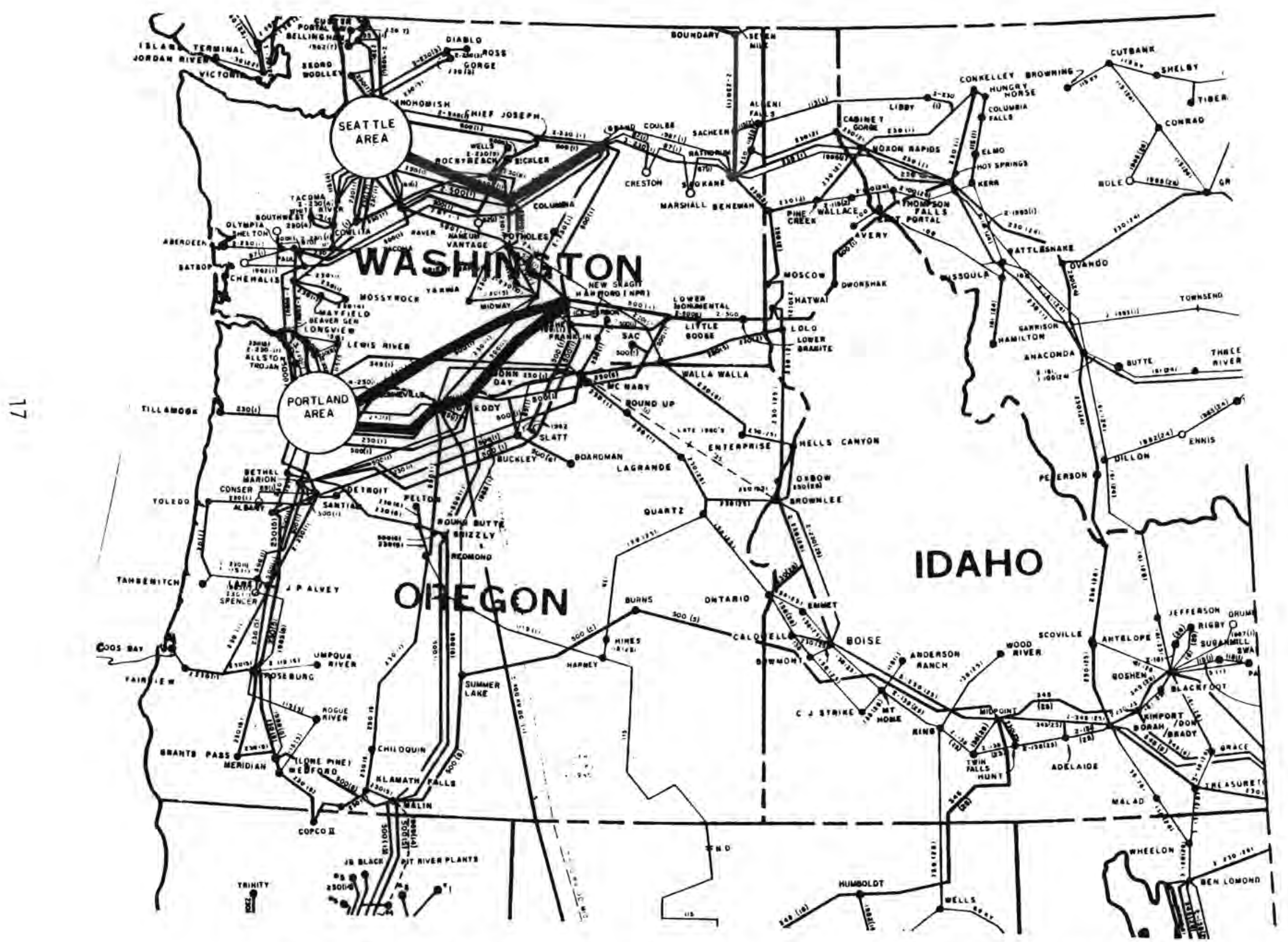

FIGURE 4. Pacific Northwest Transmission System Additions for HNEC 15,000MW Case. 


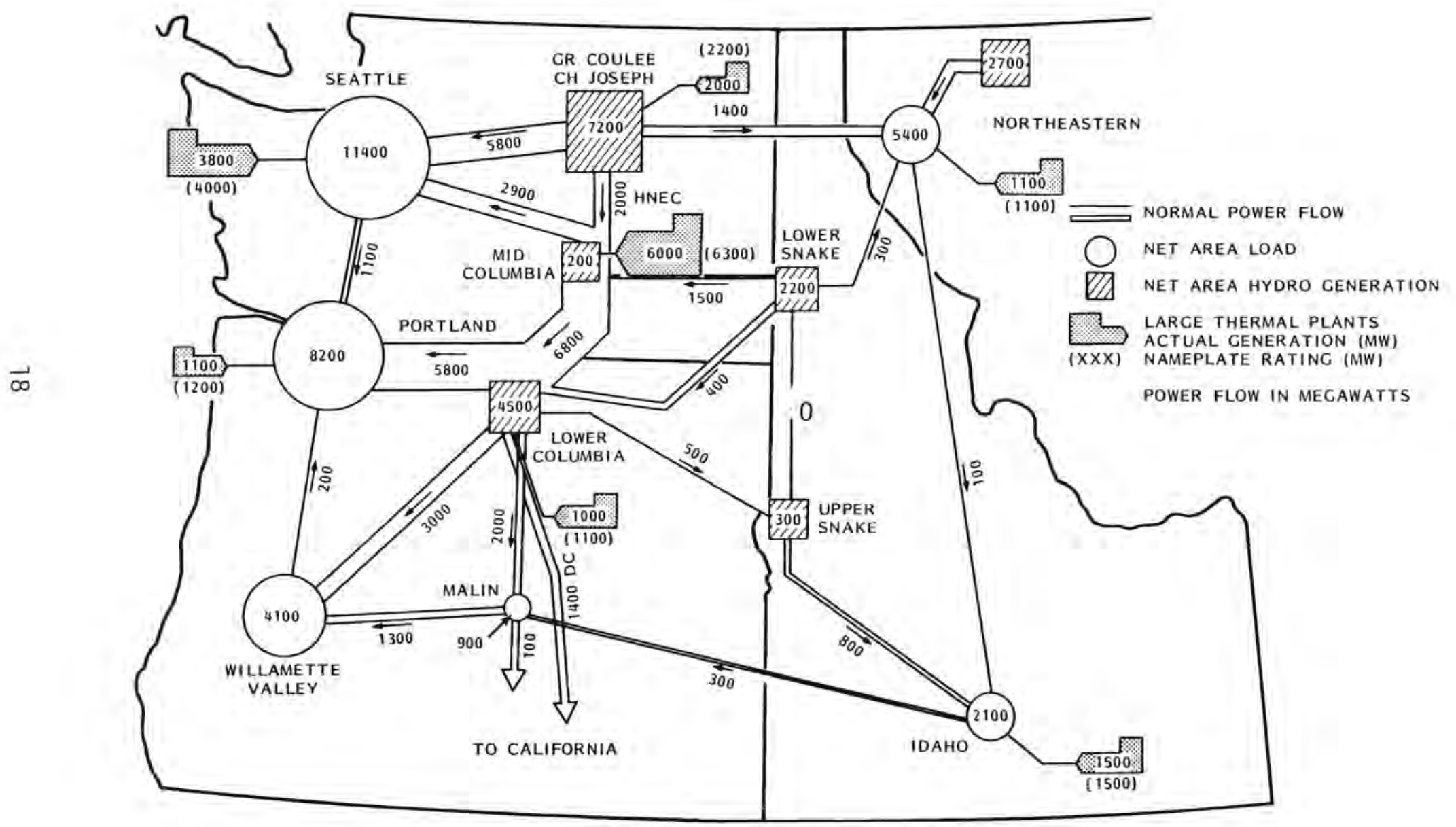

FIGURE 5. Peak Load Power Flows for HNEC 6,000 IM 


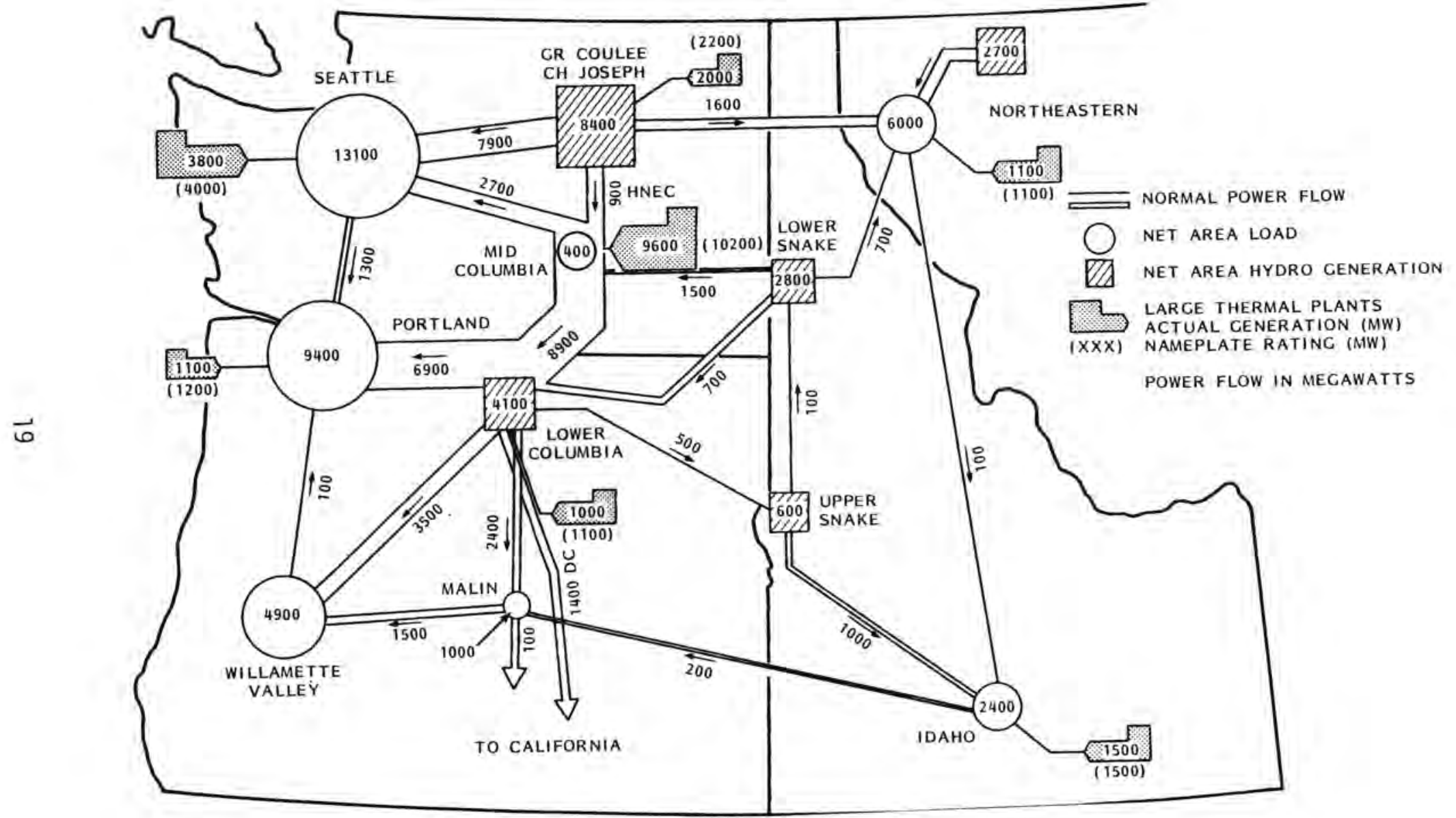

FIGURE 6. Peak Load Power Flows for HNEC 10,000 MW 


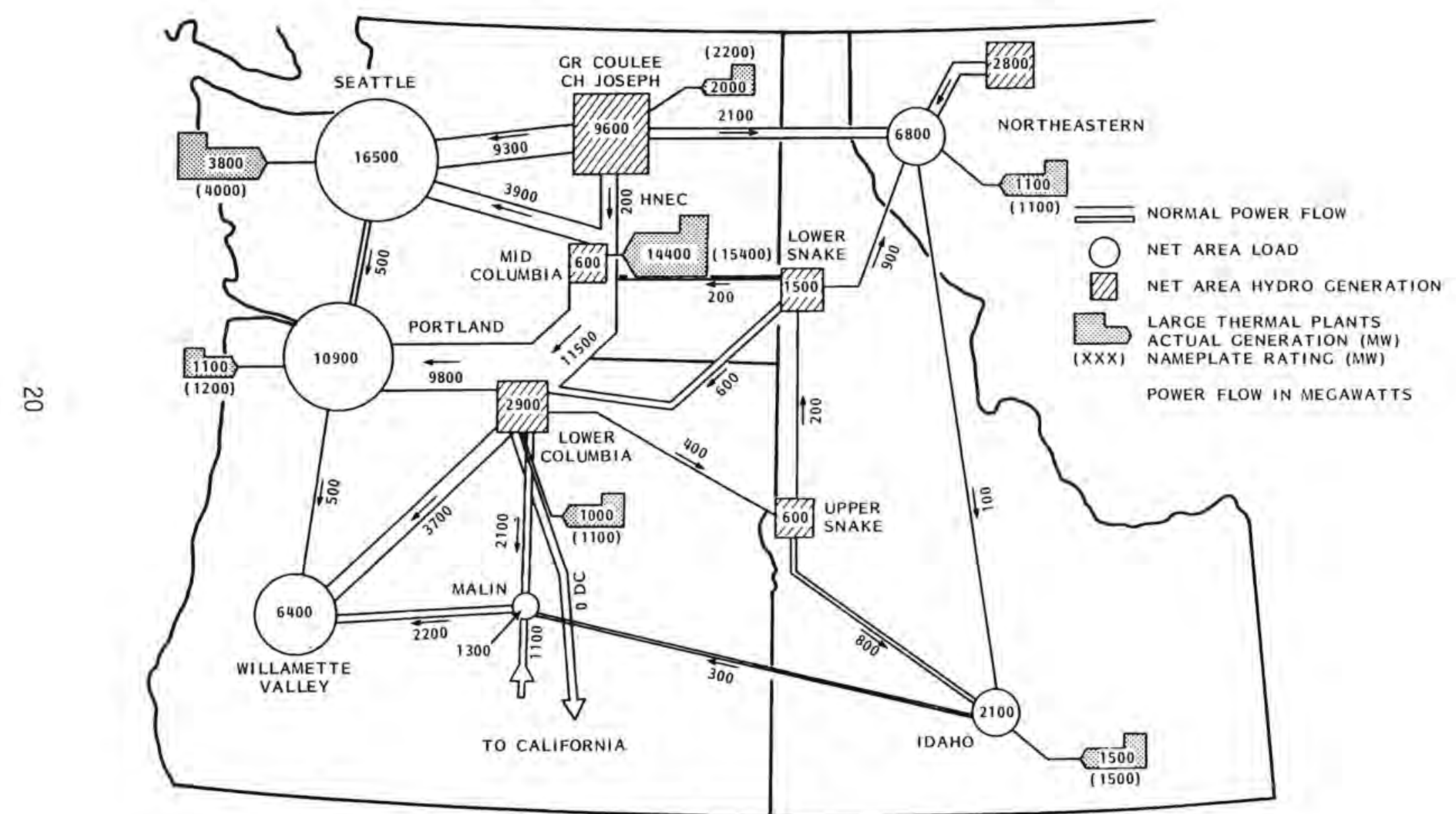

FIGURE 7. Peak Load Power Flows for HNEC 15,000 MW 


\section{Seattle Area}

Loop the $500 \mathrm{kV}$ Monroe-Maple Valley-Raver line and the second $500 \mathrm{kV}$ Monroe-Raver line into a new $500 \mathrm{kV}$ substation at Snoqualmie. Construct a second $500 \mathrm{kV}$ line from Snoqualmie to Maple Valley (25 km)(16 miles). Portland Area

Construct a second $500 \mathrm{kV}$ 1 ine from Ostrander to Pearl (32 km)(20 mi 1es).

The transmission facilities are all operating within their capabilities for the January peak conditions depicted in Figures 5 through 7 . Nominal maximum capacities have been established by BPA for transmission lines $250 \mathrm{~km}$ to $325 \mathrm{~km}$ (155 miles to $200 \mathrm{miles}$ ) in length in an interconnected network.

\section{Nominal Maximum Capacity}

\section{$1100 \mathrm{kV}$ \\ $500 \mathrm{kV}$ \\ $500 \mathrm{kV}$}

Design

$1100 \mathrm{kV}$

$500 \mathrm{kV} \mathrm{dbl}$ circuit

500 kV sgl circuit single-circuit

double-circuit

single-circuit

Standard Line Design

Conductors Per Phase

$8 \times 4.24 \mathrm{~cm} \mathrm{AAC}$ (2097 kCM)

$3 \times$ Seahawk (1869 kCM)

$3 \times$ Seahawk (1869 kCM)
$10,000 \mathrm{MW}$

$5,000 \mathrm{MW}$

$1,500 \mathrm{MW}$

\section{Series Compensation}

$30 \%$ (including $500 / 1100 \mathrm{kV}$ transformers)

$30 \%$

none

Line loadings will not, however, reach the nominal maximum capacities during the study period. The loss-savings realized by adding cross-mountain transmission lines, as described in the following section, will lead to the construction of these lines before they are required to meet the Reliability Criteria. A line is economically justified the year that the annual costs, including interest, amortization, operations and maintenance, equals the value of losses saved on the transmission grid. The schedule of transmission additions for the three HNEC levels is based on powerflow studies of the base cases and outage cases, and a cursory analysis of potential loss savings. 
Transmission line outages, or simultaneous outages of a line and a large generator in the load area, may produce temporary line flows greater than the nominal values tabulated above. However, thermal limits and receiving end voltages would be within limits established by the Reliability Criteria. Preliminary studies indicate no stability problems.

\section{$\underline{\text { LOSSES }}$}

Transmission system 1 osses are significantly reduced when a new crossmountain line is energized. For example, with 6,000 MW (5 units) at HNEC, an $1100 \mathrm{kV}$ line will decrease January peak losses by $160 \mathrm{MW}$, while a doublecircuit $500 \mathrm{kV}$ line will effect a 110 MW loss savings. With 7200 MW (6 units) at HNEC, the loss savings for an $1100 \mathrm{kV}$ line increases to $210 \mathrm{MW}$. Total system peak losses for the three HNEC levels are tabulated in Table 3.

\section{TABLE 3. System Peak Losses}

$\begin{array}{cccc}\text { Case } & \text { PNW LosS (MW) } & \begin{array}{c}\text { Unscheduled Reactive } \\ \text { (MVAR) }\end{array} \\ \text { HNEC } \quad 6,000 & 1250 & 700 \\ \text { HNEC } 10,000 & 1480 & 2300 \\ \text { HNEC } 15,000 & 1870^{(a)} & 6000^{(a)}\end{array}$

(a) Estimated - Values for the HNEC 15,000 power flow are adjusted for estimated effects in lower voltage portions of the system.

Peak loads, and hence, peak losses, are experienced only for a short period during the year. The ratio of average load to peak load is called the load factor, which is approximately 65 percent on the total PNW system. Cross-mountain line load factor is expected to be somewhat lower due to the operation of the hydro system to supply peak loads. The load factor should approach the system average as more base-loaded thermal plants are built at HNEC. This deviation must be considered when evaluating cross-mountain transmission alternatives. Losses are approximately proportional to the square of the line load. For 65 percent load factor, a loss-factor adjustment of 45 percent is applied to the peak losses in Table 3 to obtain annual energy losses. 
REACTIVE MVA

New thermal plants are expected to supply part of the reactive power (MVAR) needs of the PNW system. Additional reactive support, supplied by shunt capacitors, will be required in the load areas. Unscheduled reactive requirements for the three levels at HNEC are listed in Table 3 . It is assumed that that buildup of MVAR requirements will follow a smooth curve from zero in 1991 to the designated values at the HNEC 15,000 MW level.

\section{TERMINAL SWITCHING ARRANGEMENTS}

Conceptual bus arrangements at the HNEC substation sites are shown in Figures 8 through 10 for development of 6,000 MW, 10,000 MW, and 15,000 MW. Lines to existing $500 \mathrm{kV}$ stations and lines to other generating stations at HNEC can originate at each substation, and 500/1100 kV step-up transformers for the new cross-mountain lines can be located there. In addition, each station allows for one or two generating plants to supply possible local industrial load. Generating units up to a total of eight (including one or two for local loads) could be accommodated in each station, assuming that interrupting duty can be held within acceptable limits. Beyond that, more concentration of power in the switchyard would aggravate problems in handling fault currents; it would also be inadvisable to expose too great a portion of the system generating capacity to complete failure of a switching station.

It is likely that gas-insulated substation (GIS) equipment will, at least in part, be used at the HNEC terminals, as well as at the receiving end of the cross-mountain lines. Switching arrangements would be the same whether the station is air insulated or GIS, although the physical layout would change considerably.

One alternative to the arrangements shown is generator step-up transformation directly to $1100 \mathrm{kV}$. This option is especially attractive if an $1100 \mathrm{kV}$ tie line is established between coulee and HNEC.

Safety requirements for nuclear plants specify that two independent offsite sources of power for in-house use be available to each reactor. In modern power plant design, the normal source is the generator bus. When the generator is down, power can flow from the $500 \mathrm{kV}$ station to the station 


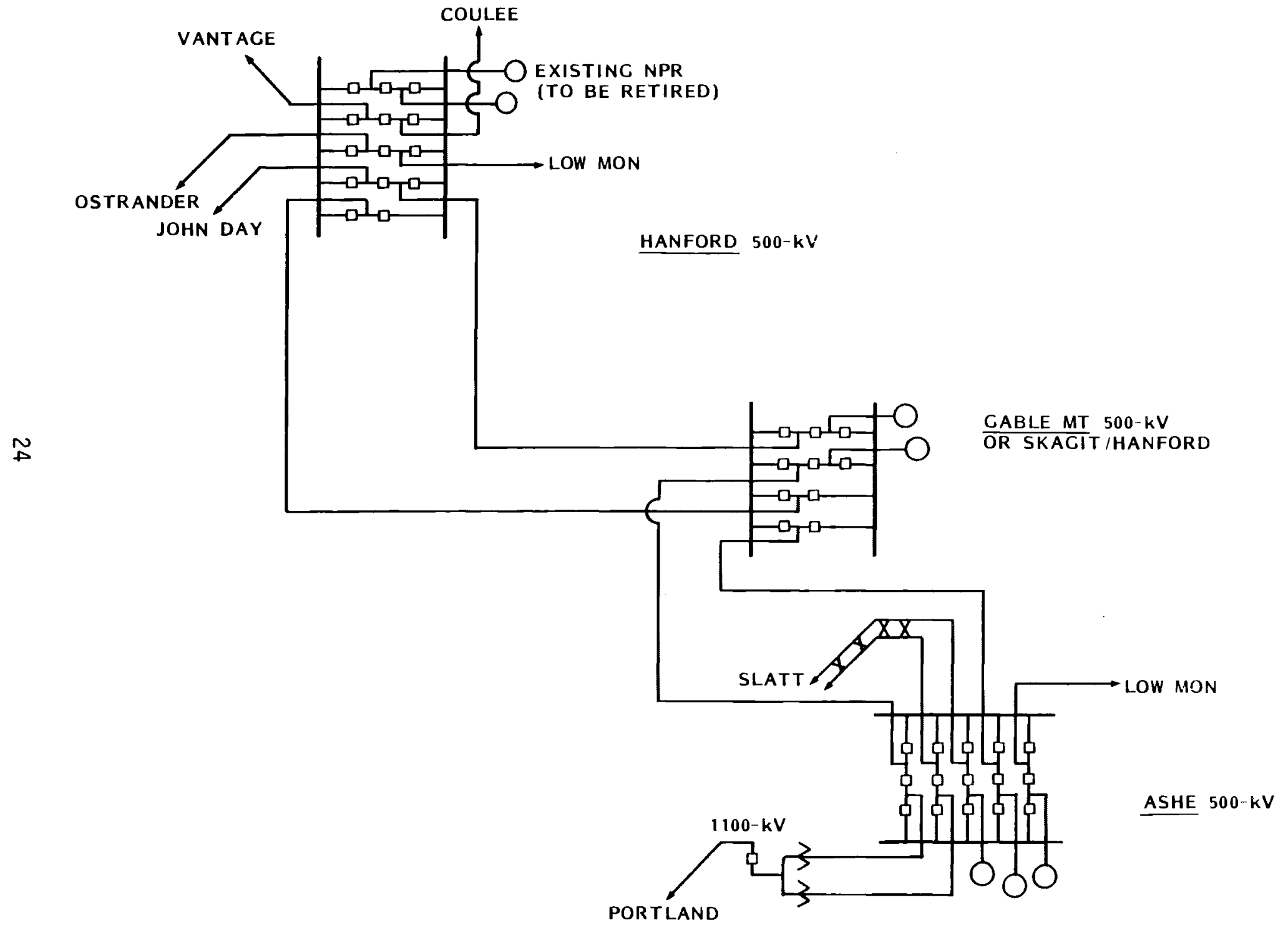

FIGURE 8. Switching Stations - HNEC 6,000 MW Case 


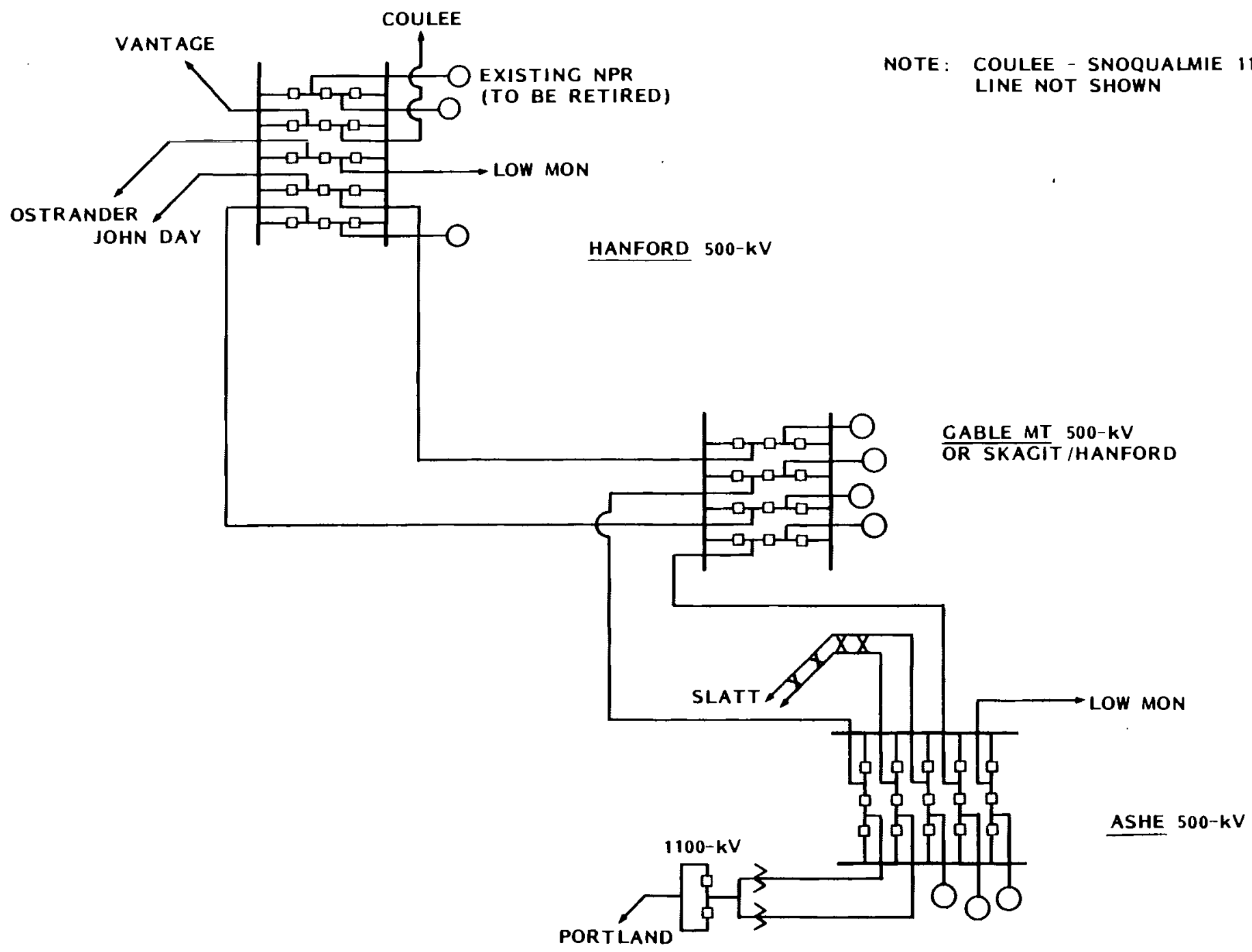

FIGURE 9. Switching Stations - HNEC 10,000 MW Case 


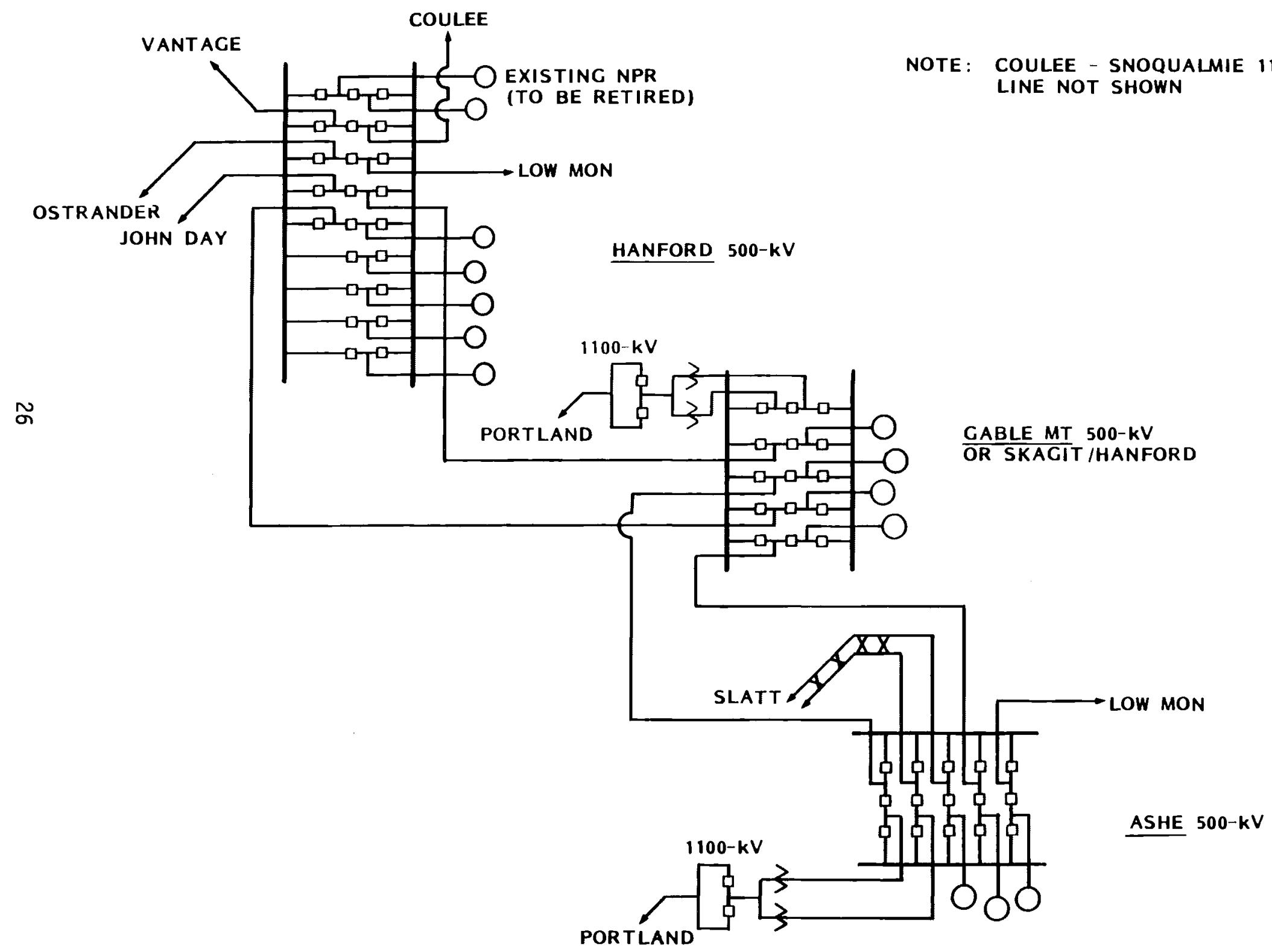

FIGURE 10. Switching Stations - HNEC 15,000 MW Case 
service transformers via the generator bus. At HNEC the alternate source can be the $230 \mathrm{kV}$ system lines in the vicinity of the plants, or the $500 \mathrm{kV}$ system, when two or more lines terminate in the switching station. The alternatives are discussed in Reference 2 , in which it was concluded that "Either of the two alternate circuit concepts, Concept A or B (230 or $500 \mathrm{kV}$ ), studied in detail would be acceptable, based on safety and operability." (Although Figures 8 through 10 do not contain detailed information on station service arrangements, such detail can be obtained from Reference 2.)

THE 50,000 MW HNEC CASE

In a long-term examination of an energy center, it is necessary to judge the limitations of the transmission system that would have evolved, specifically with respect to continuing growth of the energy center beyond 15,000 MW in generating capacity. To this end, some consideration is given in the report to expansion or adaptation of the system to accommodate net power export of up to 50,000 MN from an HNEC in the more distant future.

If $75 \%$ of the added thermal generation would flow to the west, the total flow over the Cascade Range from thermal and hydroelectric sources at peak load would be about 60,000 MW plus flow from any added eastern peaking generation.

Table 4 gives the potential capacity of rights-of-way available over the Cascades if 4 of the 12 rights-of-way are occupied by high-capacity doublecircuit $500 \mathrm{kV}$ lines and if the remaining 8 rights-of-way are occupied by single-circuit $1100 \mathrm{kV}$ lines.

A transfer capability of $87,000 \mathrm{MW}$ is shown in the table, against the somewhat lesser requirement of the HNEC 50,000 MW case, indicating ample potential for transfer capacity in available rights-of-way. The total system capability for transfer of power east to west allows a $20 \%$ reduction in the summation of pass capacities for imbalance in loading and for reliability. In this analysis the need for the $1100 \mathrm{kV}$ lines would come late enough that the technology may be expected to be well advanced and tested. 
TABLE 4. Cascade Pass Right-of-Way Capacity

\begin{tabular}{|c|c|c|c|}
\hline \multirow[b]{2}{*}{ Pass } & \multirow[b]{2}{*}{$\frac{1976}{M W}$} & \multicolumn{2}{|c|}{$\begin{array}{l}\text { Convert Cross-Mountain Lines } \\
(345 \mathrm{kV} \text { and below) to: }\end{array}$} \\
\hline & & $\begin{array}{l}\text { Tota } \\
\frac{12-5 \mathrm{GW} \text { Lines }}{\mathrm{MW}}\end{array}$ & $\begin{array}{l}\frac{a c i t y}{4-5 \mathrm{GW} \text { Lines }} \\
\frac{8-10 \mathrm{GW} \text { Lines }}{\mathrm{MW}}\end{array}$ \\
\hline Stevens & 2,600 & 6,500 & 11,500 \\
\hline Snoqualmie & 550 & 5,000 & 10,000 \\
\hline Stampede & 3,700 & 17,700 & 22,700 \\
\hline Columbia River & 2,250 & 11,500 & 16,500 \\
\hline Lolo & 1,950 & 11,200 & 21,200 \\
\hline Mt. Wilson & 1,500 & 11,500 & 16,500 \\
\hline Breitenbush & 500 & 5,000 & 10,000 \\
\hline Total Capacity & 13,050 & 68,400 & 108,400 \\
\hline $\begin{array}{l}\text { System Transfer } \\
\text { Capability(a) }\end{array}$ & 10,500 & 55,000 & 87,000 \\
\hline
\end{tabular}

(a) Includes margin for reliability

Handling that amount of power from one general area would involve many questions of system design. However, no absolute technological barrier to the accommodation of 50,000 MW at HNEC is apparent from a transmission standpoint. Growth of transmission capability along the 1 ines discussed above would be compatible with the system visualized for 15,000 MN, and could progress without disruption of system operation. 


\section{ECONOMICS}

Additional hydro capacity and some pumped storage east of the mountains are expected to come on line during the 1993 to 2000 period. The transmission system concepts for HNEC cases would serve both the new hydro capacity and the new thermal capacity at HNEC.

In this analysis no attempt is made to allocate new transmission capital or operating costs to such generating capacity; to determine or al locate urused capacity in the transmission system at the beginning or end of the growth stage; to place a value on the existing base transmission system; or to derive the system-wide average cost of transmission per unit of energy transmitted. The purpose is only to measure the incremental transmission costs resulting from a decision to add generating capacity at HNEC, to give some perspective on such costs relative to the value of the energy trarismitted, and to provide a basis for comparison of incremental transmission cost estimates for any other prospective siting of generating capacity in the region.

The capital cost estimates include major transmission lines, transformers, switching stations, series compensation, and shunt reactors. They exclude those other additions to the system which are needed but are of relatively minor economic significance.

In a11 cases the estimates are for a series of costs that come from the system additions described above, incremental to the base system costs of the transmission plant in place in 1992, and that would be incurred to accommodate the series of new thermal generating plants to be installed in the HNEC concepts. The analysis makes use of the BPA base load forecast. The significance of the analysis applies also to the other load forecasts in which both load and generating capacity grow more rapidiy.

\section{ECONOMIC GROUND RULES}

The transmission system required for the three levels of development at HNEC will be built over a period of years. In this study, conducted 
in a period of changing inflation and interest rates, no effort was made to predict cost escalation rates due to general inflationary or other effects, or to use discount rates incorporating inflationary or deflationary expectations. Rather, a real discount rate of 4 percent was used, with no escalation of costs applied to estimated capital requirements or operating expense beyond the 1982 dollar value level.

Tables containing the base data used in the economic analys is are in Appendix A.

\section{CAPITAL COST}

The incremental transmission facilities required for an additional $10,000 \mathrm{MW}$ of capacity at Hanford (from the 5,000 MW assumed to exist in the late 1990s to the 15,000 MW of the largest case) consist of three major $1100 \mathrm{kV}$ transmountain lines and two $500 \mathrm{kV}$ relatively short lines. The latter are not included in the economic analysis since they would have a relatively minor effect on the overall costs of accomodating the assumed capacity growth at Hanford.

Under the BPA base load forecast, major new 1 ines would be required in the years 2001, 2009, and 2016. Capacitors for the control of reactive KVA on the system would be added from 1992 on. The cost of these facilities is estimated at:

$\begin{array}{lr}\text { Ashe Portland } & \$ 411 \text { million } \\ \text { Grand Coulee Snoqualmie } & 424 \text { million } \\ \text { Gable Mountain Portland area } & 411 \text { million } \\ 6,000 \text { MVAR Capacitors } & 36 \text { million }\end{array}$

Table 5 contains the schedule of transmission capital funding requirements as capacity at Hanford increases from 5,000 to 15,000 MW. 
TABLE 5. Schedule of Capital Expenditures*

\begin{tabular}{lr} 
Year & \$Mi11ion \\
\hline 1992 & 0.4 \\
1993 & 0.4 \\
1994 & 2.0 \\
1995 & 3.6 \\
1996 & 3.6 \\
1997 & 30.5 \\
1998 & 45.6 \\
1999 & 247.6 \\
2000 & 81.0 \\
2001 & 0.4 \\
2002 & 2.8 \\
2003 & 4.5 \\
2004 & 4.5 \\
2005 & 32.3 \\
2006 & 47.9 \\
2007 & 256.2 \\
2008 & 84.2 \\
2009 & 2.8 \\
2010 & 6.4 \\
2011 & 6.4 \\
2012 & 33.2 \\
2013 & 48.4 \\
2014 & 250.4 \\
2015 & 83.7 \\
2016 & 3.2 \\
& 1282.0
\end{tabular}

*BPA Base Load Forecast 


\section{OPERATING AND MAINTENANCE COSTS}

Operating and maintenance costs are estimated at:

$\begin{array}{lr}\text { Ashe-Portland } & \$ 2.7 \mathrm{million} / \text { year } \\ \text { Grand Coulee-Snoqualmie } & 2.8 \mathrm{million} / \text { year } \\ \text { Gable Mountain-Portland area } & 2.7 \mathrm{million} / \text { year } \\ \text { Capacitors } & \$ 425 / \text { MVAR/year }\end{array}$

These values are used in the computations of annual costs to follow.

\section{LOSSES}

The value of losses is based on BPA "time-differentiated long-run incremental cost analysis". The expression for the annual cost of losses per peak $\mathrm{kW}, C_{L}$, is :

$$
C_{L}=\$ 0.042(8760)\left(L_{0} F\right)+\$ 54\left(1-L_{0} F\right)
$$

where $L_{0} F$ is the loss factor, in this case 0.45 .

Year-to-year losses as loads build up and as additional transmission lines are added are given in Table 6 .

Three major effects may be seen. First, the addition of the Ashe-Portland $1100 \mathrm{kV}$ line reduces system losses, and results in a loss credit for a few years. Second, since losses are a function of the square of the current carried in the lines, the losses build up rapidly as the lines become more fully loaded. Third, the curve of losses is sawtoothed, with stepped decreases occurring as new transmission lines come into service. A third effect, not shown in the table, is the reduced losses in an $1100 \mathrm{kV}$ line for a given level of power transmission, relative to those in alternative $500 \mathrm{kV}$ Tines.

The losses shown in Table 6 are included in the overall costs of energy delivery.

SUMMARY OF ANNUAL COSTS

Table 7 contains estimates of year-to-year fixed charges on capital, operation and maintenance costs, and cost of losses. 
TABLE 6. Estimated Cost of System Losses

Resulting from Load Growth and Transmission Line Additions

\begin{tabular}{cccc} 
Year & $\begin{array}{c}\text { Peak System } \\
\text { Losses, MW }\end{array}$ & $\begin{array}{c}\Delta \text { Losses } \\
\text { MW }\end{array}$ & $\begin{array}{c}\text { Value of } \\
\Delta \text { Loss }\end{array}$ \\
\cline { 2 - 3 } 2000 & 1410 & 0 & $\begin{array}{c}\text { \$ Milion } \\
0\end{array}$ \\
2001 & 1250 & $(160)$ & $(31.2)$ \\
2002 & 1301 & $(109)$ & $(21.3)$ \\
2003 & 1352 & $(58)$ & $(11.3)$ \\
2004 & 1403 & $(7)$ & $(1.4)$ \\
2005 & 1455 & 45 & 8.8 \\
2006 & 1507 & 97 & 18.9 \\
2007 & 1559 & 149 & 29.1 \\
2008 & 1661 & 201 & 39.2 \\
2009 & 1480 & 70 & 13.7 \\
2010 & 1562 & 152 & 29.7 \\
2011 & 1644 & 234 & 45.7 \\
2012 & 1726 & 316 & 61.7 \\
2013 & 1809 & 399 & 77.9 \\
2014 & 1892 & 482 & 94.1 \\
2015 & 1975 & 565 & 110.3
\end{tabular}

(a) From 1410 MN Base

(b) Based on BPA TDLRIC Unit Power Value 
IABLE 7. Total Annual Costs and Energy Transmitted, System Additions Through 2015

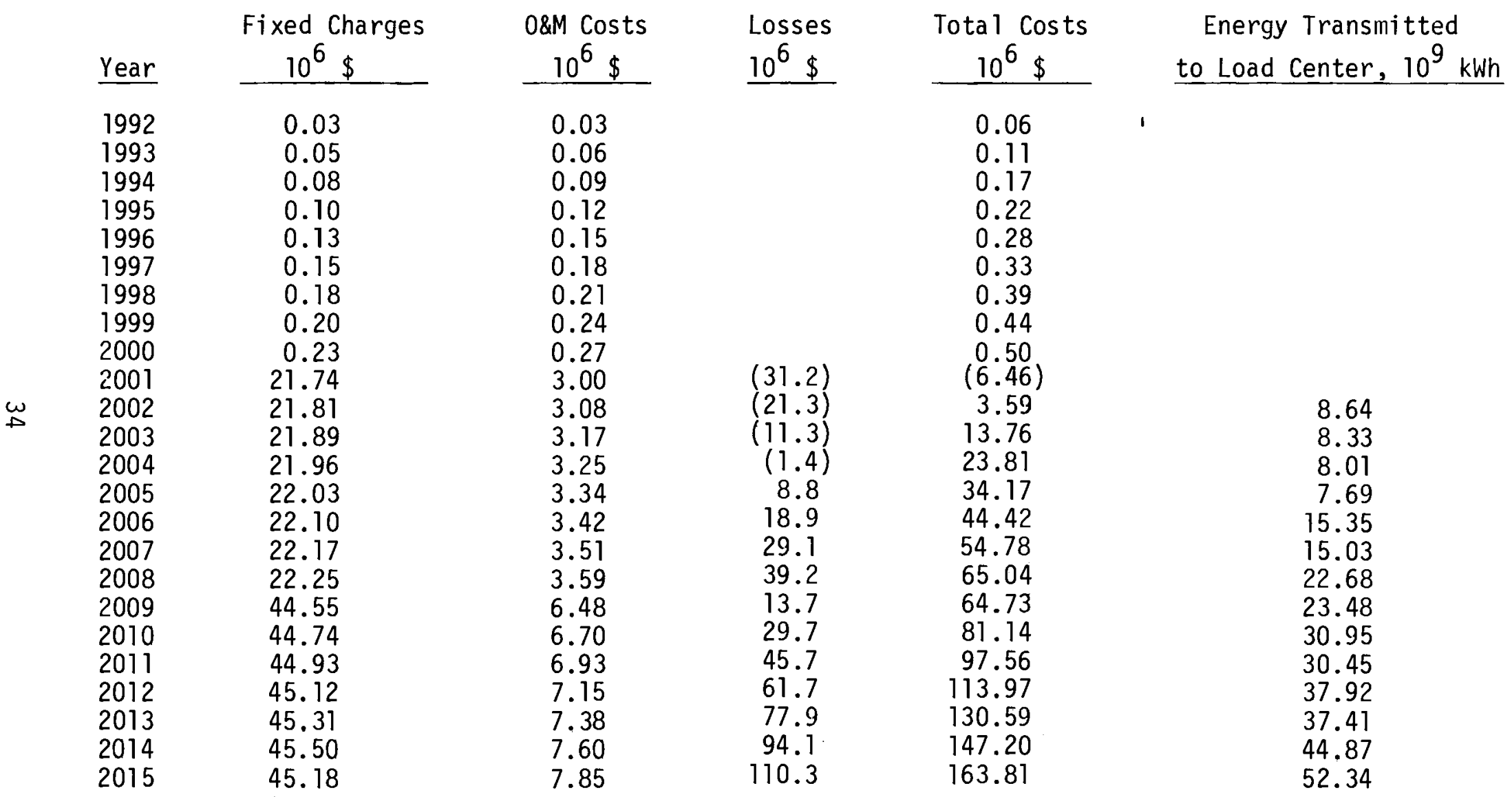


These estimates are for an increment of two major lines to the transmission system to accommodate an increment of $9100 \mathrm{MW}$ of generating capacity at Hanford.

Fixed charges on capital expenditures and interest-during-construction were computed for the various types of equipment. Fixed charges begin the year the line goes into service. These were added to the 0\&M and loss cost estimates to obtain total annual costs.

Energy delivered to load centers is computed by subtracting incremental transmission system losses from the rated output of the HNEC plants, year by year during the period. Energy deliveries, based on an a-erage $70 \%$ generating plant load factor, are also shown in Table 7. In the Table, it is assumed that revenue from the sale of electricity delivered to load centers must cover all costs of transmission, including capacity and energy losses in the transmission system (losses as shown in the Table).

The estimated unit cost of transmission for the increment of generation being studies is 3.0 mills per kilowatt hour, which is about $7 \%$ of the estimated value of the energy at the generating plant busbar.

The sensitivity of the $7 \%$ figure to the estimated value of energy is:
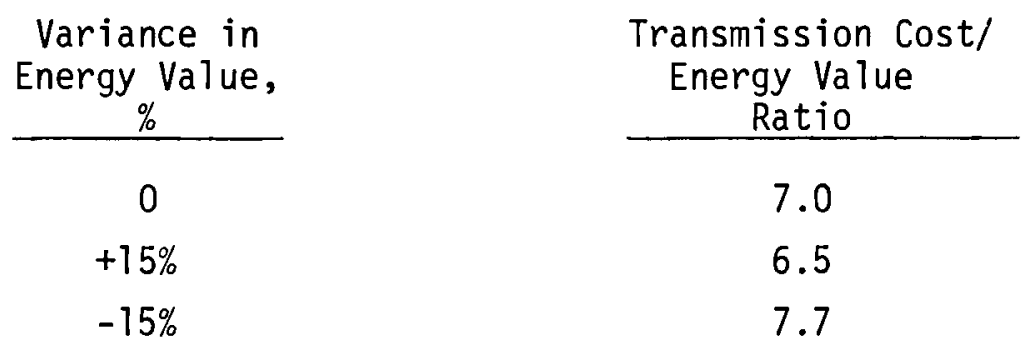

This does not reflect the total system average cost of transmission, since the figures do not include the base system facility costs or energy deliveries.

In conclusion, for an increment of approximately 10,000MW of thermal generating capacity at HNEC (from the 5,000MW assumed to exist at the beginning of the period to $15,000 \mathrm{MW})$, the price of bulk power at the load centers would be expected to be from 6.5 to $7.7 \%$ higher than the price at the busbar, due to the costs of transmission from the Hanford site. This increase may be compared with the estimated incremental costs of transmission from alternative generating sites. 



\section{ANALYSIS OF SYSTEM CONCEPTS}

This section of the report briefly examines the reliability, reserve, technological development and environmental aspects of the growth of generating capacity at HNEC up to 15,000 MW.

\section{RELIABILITY}

The reliability of the PNW transmission system as it would be affected by the concentration of thermal generating capacity at HNEC, as epitomized in this study, can be assessed by examining the probability and consequences of system disturbances, i.e., the probable frequency of outages, the amount of load to be dropped, and the duration of the service interruption.

The economy of system design requires that although many kinds of disturbances and equipment failures can be accommodated without any loss of load, other kinds would involve temporary loss of load in certain areas in the process of isolating the troubled area and thereby protecting the rest of the system. Criteria governing the design of the system determine where the line is drawn between accepting some loss of load and investing in more capital plant to avoid any loss of load. The reliability criteria now in effect would apply to the transmission system additions.

Technology of $1100 \mathrm{kV}$ transmission is now available and proven. Substation equipment design basically is scaled up from that of $500 \mathrm{kV}$ equipment. While power flow on an $1100 \mathrm{kV}$ line is greater than that on a $500 \mathrm{kV}$ line the system is designed to meet present Reliability Criteria. If $1100 \mathrm{kV}$ facilities are added for loss savings before they are needed for reliability, then operating experience can be gained in the interim period.

\section{Exposure}

Exposure to transmission system outages, which may or may not involve load outages, would be somewhat greater with 10,000 to 15,000 MW of generating capacity at HNEC than it is presently, because of (a) more miles of transmission line, (b) more power carried over certain rights-of-way, and (c) a 
considerable concentration of both switching station equipment at HNEC and of transmission lines in the general vicinity of the Center. Category (a) could add some exposure to line equipment failure, but such failures would normally be accommodated without load dropping and may be eliminated as a source of potential downgrading in reliability.

Exposure to damage from external causes is of more concern. Possible causes that could act upon exposure categories (b) and (c) are listed below:

\section{Possible Cause of Failure}

Tornado

Flood

Avalanche

Brush fire

Icing from storms

Earthquake

Aircraft crash

Sabotage

Ashfall from Cascade volcanoes

Abnormal conditions at adjacent nuclear plants; radioactive discharge as affecting accessibility Military attack(a)
All Lines in Rights-of-Hay

$x$ $x$ $x$

$x$

$x$

$X$

$\begin{array}{ll}x & x \\ x & - \\ x & x \\ x & x \\ x & x \\ x & x\end{array}$

$x$

$x$

\section{Switching Stations} $x$

(a) Consequences of military acts are to be considered in other studies.

As mentioned previously, in the current economic climate additional lines can be justified by reduction in losses before they a re required for reliability. This trend tends to offset the negative effects of added exposure on system reliability by providing additional alternate flow paths in the network. Other considerations follow.

\section{Line Outages}

Line outages as discussed here include both circuits of a double-circuit line. The following statements refer to steady-state conditions with load 
shifts made under stable conditions. Transient stability effects are discussed in a latter section on stability.

In the simulated system tests the HNEC design concepts respond to the loss of any line without interruption of service to loads on any part of the system. The most heavily loaded line will carry about 5,000 MN just before a second $1100 \mathrm{kV} l i$ ine is added to the Portland area for the 15,000 MW case. Load on that line, or on any other line considered crucial, would be shifted to other lines of the network without any loss of load. Although a particular line may be more heavily loaded than presently, more spare capacity is provided in other lines in the network, and the consequences (no load loss) would be unchanged.

\section{Loss of All Lines in a Right-of-Way}

The design criteria permit some controlled dropping of interruptible and firm load in the event of loss of all lines in a right-of-way. This could cause loss of more load in the future when east to west transfers would be greater than at present. However, if a single right-of-way would have only one major line, along with one or two $230 \mathrm{kV}$ single-circuit lines, $80 \%$ of the capacity in the right-of-way would be in the major line. If system design is such that the loss of the major line could be accommodated without any loss of load, the chances are that in most situations simultaneous loss of the minor lines could also be accommodated.

If the major lines described heretofore were placed in separate rightsof way, the difference in reliability of the two concepts for loss of all lines in a right-of-way would probably be insignificant.

\section{Loss of an Entire Switching Station}

Under the design criteria, loss of an entire switching station could entail dropping of some interruptible and firm load, and dropping of generators. In the HNEC cases, since a large amount of generating capacity is connected to a single switching station substantial load may be dropped. 
However, here again extenuating circumstances exist in that the two adjacent thermal generating groups and the hydro plants in the eastern part of the state with their reserve capacity may be able to pick up most or all of the generating deficit. All generators on one switching stations would constitute from 10 to $14 \%$ of total on-line system generating capacity depending on the stage of development and the point in the loading condition at the time.

Although loss of an entire switching station could have serious reliability consequences with the HNEC concepts, the probability of such a loss is very low. The switching structure and apparatus would be spread over many acres, and under ordinary conditions it is highly unlikely that a section in trouble could not be isolated; thus, the amount of generation lost in a specific incident may not be highly disruptive.

The risk of interruption of up to 8.4 GW power flow at an HNEC switching station serving seven generating units, because of a disastrous event affecting the station, is evaluated in Reference 4 . The probability of occurrence of such events is given in Table $\&$ taken from the referenced document. From the table, the probability of a major power interruption at a switching station because of the occurrence of any of these events is $4.3 \times 10^{-6}$ per year, or once in 230,000 years. The estimated probable time in which the station could be returned to service following such an event is 25 days.

\section{TABLE 8. Risk of Interruption of $50 \%$ or More of the} Power Flow through a Switching Station

Probability,

Tornado

Aircraft crash

Flood

Earthquake ${ }^{(a)}$

Radioactive release ${ }^{(a)}$ Ashfa11 (a) Events/Year

$4.0 \times 10^{-6}$

$1.7 \times 10^{-7}$

$1.0 \times 10^{-7}$

Probable Outage

Time, Days

(a) Failure of a switching station from such events would add nothing to the risk of loss of generation on the system arising from the impact of the same event on the generating plants feeding into the switching station. 
From these estimates, HNEC switching station exposure to external events would not significantly reduce the reliability of the transmission system.

Relay misoperation and operator error are more likely causes of loss of part or all of a switching station, but the probabilities of such events have not been estimated.

Simultaneous Loss of Two HNEC Switching Stations

As analyzed in Reference 4, single events that are sufficiently widespread to impinge on two switching stations simultaneously (1imited to earthquake, ashfall, and flood from a Grand Coulee Dam failure) would also cause failure of the generating plants. Therefore, the switching station risk adds nothing to the overall risk of loss of generation to the system. Conceivably a single tornado could strike two switching stations without affecting the generating plants, but the probability is very low, of the order of $7 \times 10^{-7}$ events per year (once in 10 million years).

\section{Failure to Clear High-Current Faults}

As noted under a following section on "Technological Development Aspects," the high fault currents of an HNEC with the bus arrangements shown would be close to the limit of present state-of-the-art interrupting capacity. It is assumed that future development effort will further increase the capacity ratings and reduce clearing times. If so, the reliability of fault clearing equipment would presumably be adequate. If adequate development results have not been achieved by the time of need, the design would have to be such as to limit fault currents by subdivision of buses, use of reactance, or other measures, at added cost.

The extent to which an HNEC might be vulnerable to major power interruptions from failure to clear high-current faults is explored in Reference 4. The major concern is that the first two circuit breakers in the protective sequence would fail to clear the fault thus precipitating system instability. The probabilities entering into an assessment of risk are:

1. The probability of occurrence of the causative event, i.e., a heavy short circuit or ground on the transmission system,

2. The probability of successive failure of two breakers for any reason (some failures are not due to high fault currents), and 
3. The probability of the system becoming unstable before further backup breakers have cleared the fault.

In the comparative positions of HNEC 15,000 MW and the present system with respect to these probabilities, there is no clear difference in Items 1 and 2, but there is some disadvantage to the more highly-developed HNEC in Item 3. The disadvantage would be with the uncleared fault being near a larger block of generation. Estimates of the numerical value of probabilities 1 and 3 were not available. The value of Item 2, the failure rate of modern circuit breakers, is 0.005 (once in 200 attempts) for each breaker.

Even though HNEC, 10,000 to $15,000 \mathrm{MW}$, is at some disadvantage in the above comparison, the frequency of a failure-to-clear event would be very low as determined by the presence of the factor $(0.005)^{2}=0.000025$. It can be concluded that under the above assumptions the reliability of the transmission system would not be significantly downgraded by HNEC exposure to greater fault currents.

\section{Stability}

The Pacific Northwest system of 1993 with its "distributed" hydro and thermal generation will be a closely coupled system, with internal interconnecting transmission lines of relatively high capacity, thus enhancing internal system stability. The greatest stability problems would be those concerned with angular swings between the Pacific Northwest and Interconnected adjacent systems, those of California, Canada, Idaho, and Montana.

In the HNEC case of maximum development internal system stability will be maintained if the total capacity of the ties between HNEC and existing generating stations are proportionately as great as that which now exists in the interconnections between Grand Coulee and other generating plants. Preliminary studies indicate that the requirement would be met by the systems described heretofore for both cases.

Although thorough stability studies have not been conducted on the HNEC cases, preliminary studies indicate that the angular swings occurring when major loads or lines are lost would not be excessive and could be kept within 
acceptable limits by means now employed in various places on the system. These include fast fault clearing (one cycle breakers), dynamic braking resistors, fast relaying, and controlled dropping of generators and/or loads.

The results of the preliminary study on stability are summarized below:

- Internal system stability could probably be maintained without great difficulty in the HNEC concepts.

- Stability between the PNW and adjacent systems will be affected in much the same way as at present, the major consideration being the total increase in generating capacity relative to the capacity and loading of tie lines with other systems.

To summarize the foregoing section on reliability:

- HNEC 10,000 to 15,000 MN would be exposed to a very low-probability class of events that could affect reliability adversely relative to present systern reliability and that class of events could not be compensated reasonably by system design measures.

- In other exposure classifications the HNEC concept has reliability essentially equal to that of the present system.

\section{RESERVES}

The existence of a nuclear energy center conceivably could affect the amount of the reserves that would be necessary because of 1) a: transmission pattern that would be different than for a system with more distributed generation, and 2) a potentially better situation in which to maintain generating plants and make emergency repairs on them. Only the first of these possible influencing factors is considered here, the second being a part of the larger HNEC study.

The Pacific Northwest Utilities Conference Committee (PNUCC), in which the Bonneville Power Administration is a participant, has adopted a criterion of determining reserve requirements based on the larger of either 1) a reserve margin of $12 \%$ of estimated peak loads for the coming year of a resource schedule, increasing by $1 \%$ each year until a $20 \%$ margin is reached, or 2) the reserves required to maintain an annual probability of load loss equivalent 
to 0.5 plus one-half year's load growth. In the first method, the lower reserve levels in the early years reflect the predominance of inherently more reliable hydro generating units in the system. The higher levels in the later years are intended to reflect the impact of adding large thermal plants with higher outage factors to the present system.

It is expected that in the future the reserves will be provided largely by hydro plants and pumped storage installations, but that under certain conditions reserves will also be maintained in thermal plants. The reserve capacity has been and will be available to loads throughout the system under the same transmission conditions prevailing normally.

The amount and placement of reserve capacity are therefore largely independent of the placement of thermal generation for both spinning and other operating reserves.

\section{TECHNOLOGICAL DEVELOPMENT ASPECTS}

In the HNEC concept, in which 4 to 8 generating units may feed into one switching station, and with adjacent groups of plants that could make important contributions to current at a fault near the switching station, fault currents could exceed the ratings of circuit breakers now available.

The HNEC 15,000 MW case allows an available fault current of 50 to $60 \mathrm{kA}$ which is within the interrupting capacity of modern circuit breakers. Within the last two decades the interrupting time of circuit breakers has been reduced from 8 cycles of the power frequency to two cycles, and at $500 \mathrm{kV}$ the standard rating is $40 \mathrm{kA}$ and two cycles. Breakers capable of interrupting up to $100 \mathrm{kA}$ in two cycles at voltages up to $800 \mathrm{kV}$ are available. Additional research is proceeding in the development of relay-breaker combinations at above rating capable of interrupting faults within one cycle after initiation.

\section{ENVIRONMENTAL IMPACT}

The environmental effects of the HNEC transmission concept presented herein would be mainly in the categories of visual impact and the amount of land used for rights-of-way. Study of the biological effects of the electrostatic and electromagnetic fields near $1100 \mathrm{kV}$ lines is continuing. Voltage 
gradients in space at the edge of the right-of-way can be kept to the values for existing lower voltage lines by conductor design and possible use of shield wires.

Differences in visual impact would occur wherever 1100 or $500 \mathrm{kV}$ towers were added or where they would replace 230 or $345 \mathrm{kV}$ line towers. These towers are larger than the lower voltage towers (Figure 11). In the HNEC cases there would be one additional cross-mountain line of approximately 180 miles in length for each of the three stages of capacity growth. Although the higher voltage towers are larger, they have only minor added visual impact on most observers when seen in open countryside without a frame of reference for size.

Amounts of 1 and that would be required over and above that already in use for transmission rights-of-way are listed in Table 9. After the construction of the Ashe-Portland 1 ine at the $6000 \mathrm{MW}$ stage of HNEC development, the new 1 and requirements of the additional 1 ines to accommodate the 10,000 and 15,000 $\mathrm{MW}$ cases are relatively small.

TABLE 9. Summary of Land Use

Additional Rights-of-Way for Cross-Mountain Lines

\begin{tabular}{|c|c|c|c|}
\hline \multirow[b]{3}{*}{ Land Use } & \multicolumn{3}{|c|}{ Incremental Right-of-Way } \\
\hline & & $\mathrm{km}^{2}$ (Acre) & \\
\hline & HNEC 6,000 & HNEC 10,000 & HNEC 15,000 \\
\hline Agricultural & $6.27(1550)$ & $0.99 \quad(245)$ & 0.05 \\
\hline Rangel and & $3.76 \quad(930)$ & $0.91 \quad(225)$ & 3.93 (971) \\
\hline Forest Lane & $1.04 \quad(257)$ & $1.29 \quad(318)$ & 0.22 \\
\hline Residential/Industrial & 0.12 & 0.00 & 0.13 \\
\hline Tota 1 & $11.19(2767)$ & $3.19 \quad(788)$ & $4.33(1068)$ \\
\hline
\end{tabular}

Note: 1. Assumes utilization of existing right-of-way by replacing existing lower voltage lines with higher capacity lines.

2. Lolo Pass ultimate capacity is for two $1100 \mathrm{kV}$ lines (HNEC 6,000). Second 1ine, HNEC-Portland, assumed to use Satus Pass (HNEC 15,000). 


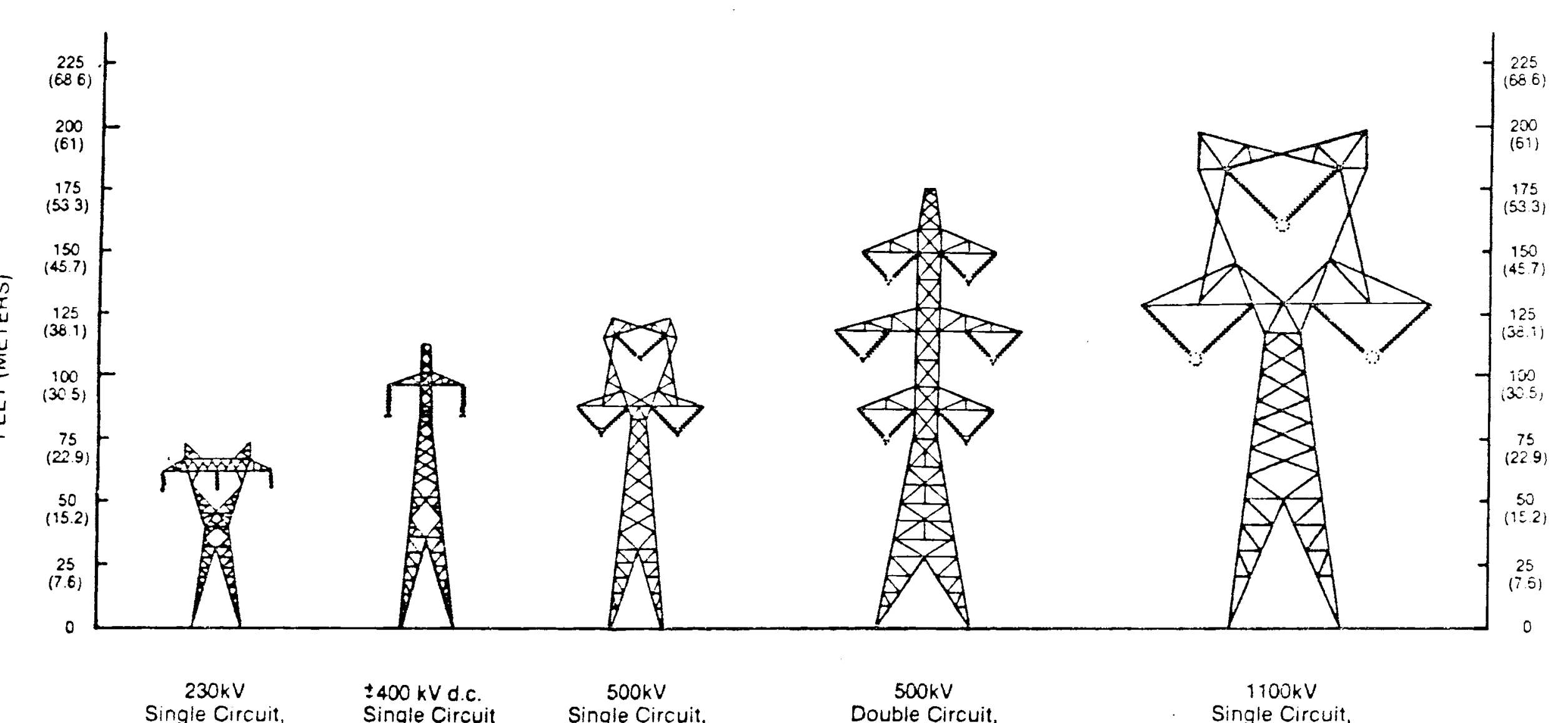


The use of the large towers will result in increased risk to migratory birds. Mortality resulting from collision with radio and television towers located along migration routes has been well documented but has not been shown to significantly affect population levels. These collisions normally occur at greater heights than the planned transmission towers. The role of transmission facilities in the electrocution of birds is difficult to evaluate since there is little quantitative information available concerning mortality. Electrocution involves simultaneous touching of two conductors or one conductor and ground. Large hawks and owls are more susceptible to electrocution than smaller birds. Recent studies have shown that there is little danger of electrocution for even large birds of prey on steel towers since these towers have widely spaced conductors.

The prairie falcon and American peregrine falcon are two species threatened with extinction (U.S. Fish and Wildlife, Resource Publ. 114) that are likely to come in contact with the proposed transmission corridors. The prairie falcon nests in the bluffs along the Columbia River and forages out over nearby grassland areas in search of prey. The American peregrine falcon also nests along bluffs and cliffs, but it is more secretive. There are no known peregrine nests in the vicinity of the transmission corridors but adults may cross them during migration and while foraging. Several pairs of nesting prairie falcons have been seen near Hanford along the Columbia River. Construction and maintenance activities along the transmission line corridors are not expected to have any adverse effects on either species.

The potential exists for some environmental degradation associated with the removal of existing $230 \mathrm{kV}$ circuits and construction of $1100 \mathrm{kV}$ single circuit or $500 \mathrm{kV}$ double-circuit lines. Erosion can occur as a result of vegetation removal and road construction activities. Generally, erosion is more of a problem in forested areas with heavy rainfall, but the slow rate of vegetation recovery in semi-arid regions can result in significant wind erosion problems. Both soil erosion and increased exposure to direct sunlight can adversely affect aquatic environments by increasing turbidity and sediment iuad which lowers overall stream productivity. The clearing of cover along stream banks exposes the stream to direct sunlight resulting in increased water temperatures. Higher water temperatures reduce the oxygen-holding 
capacity of the water and increases the metabolic rate of water-dwelling organisms. These effects are minimized by maintaining suitable cover along stream beds.

Maintenance of transmission line right-of-way would be expected to have only a minimal effect as compared to the original construction impact as long as vegetation is permitted to become reestablished beneath the 1 ines. Vegetation control beneath the lines serves to maintain the plant community in a permanent successional stage but does not greatly reduce the availability of suitable wildlife habitat.

Little environmental impact is anticipated. Some additional potential exists for adverse impact from the greater transmission line mileages in agricultural, rangeland, and forestland habitats associated with system growth. There are no rare or endangered species that would be adversely affected by construction of the HNEC transmission design. 


\section{$\underline{\text { REFERENCES }}$}

1. United States Nuclear Regulatory Commission, NUREG-001, Nuclear Energy Center Site Survey, 1975, January 1976.

2. R. L. Richardson, W. J. Dowis, BNWL-2076 Station Service Power Supply for a Hanford Nuclear Energy Center (HNEC).

3. R. D. Dunlop, R. Gutman, and P. P. Marchenko, Analytical Development of Loadability Characteristics for EHV and UHV Transmission Lines, IEEE PES Winter Meeting, January 29, 1978.

4. R. G. Clark, W. J. Dowis, BNWL-2474 Reliability of Generation at a Hanford Nuclear Energy Center (HNEC), Pacific Northwest Laboratory, June 1978. 


\section{REFERENCES NOT CITED}

Biological Studies Task Team, Bonneville Power Administration, Electrical and Biological Effects of Transmission Lines: A Review, June 1977 .

Garver, L. L., J. J. LaForest, and S. C. Robison. October 1975. Transmission Costs as Affected by Energy Center Size. General Electric Company, Schenactady, New York. Electric Utility Systems Engineering Department. Preliminary Report.

GPU Service Corporation. December 1974. Energy Park Development, Transmission Study.

National Electric Reliability Council, Apri1 1975. Nuclear Energy Centers: An Assessment of Impact on Reliability of Electric Power Supply. Technical Advis ory Committee, Interregional Review Subcommittee. Princeton, New Jersey.

Reister, D. B. and L. W. Zelby, "A Comparison Between Dispersed Nuclear. Power Stations and a Nuclear Energy Center at a Hypothetical Site on Kentucky Lake, Tennessee," Vol. II, Transmission of Power, ORNL-TM-5014.

Ringlee, R. J. and J. W. Beck, December 1974. An Assessment of Policies and Technical Factors Affecting the Degree of Interconnection of Electric Utilities in the U.S. Power Technologies, Inc., Schenectady, New York. 
APPENDIX

Unit Cost Estimates

Used in the Economic Analysis Section 
TABLE A-1. Cost Estimating Data

$1100 \mathrm{kV}$ Line Ashe-Portland

1982 Dollars $\times 10^{6}$

Item

Inves tment

Annua 1 08M

1. Line $290 \mathrm{~km}$

$(8 \times 4.24 \mathrm{~cm} \mathrm{AAC})$

318

0.3

Service Life

$\left(Y_{r}\right)$

50

2. Transformers

40

0.5

35

( 4 × 3000 MVA banks $)$

3. Shunt Reactors

30

1.2

35

(1920 MVAR)

4. Series Capacitors

(1100 MVAR)

5. Swjtching

$\begin{array}{lll}\text { KV PCBs) } & \frac{6}{411} & \frac{0.1}{2.7}\end{array}$

Note: 1. Items 1,3 , and 4 are $3.4 \%$ higher for Coulee-Snoqualmie $(300 \mathrm{~km} / 290 \mathrm{~km}=1.034)$

2. Annual O\&M costs are estimated for $1100 \mathrm{kV}$ equipment based on $500 \mathrm{kV}$ experience. Direct and indirect maintenance operations, administrative and general included.

3. Equipment service lives in the BPA cost of service analysis (COSA) are:- steel lines - 39 yrs, substation - 28 yrs. Longer lives are assumed for $1100 \mathrm{kV}$ based upon no replacement due to obsolesence.

TABLE A-2. $500 \mathrm{kV}$ Shunt Capacitors

for Unscheduled Reactive

Investment

Annual 0\&M

Service Life
$\$ 6000 /$ MVAR

$\$ 425 /$ MVAR

28 years 
TABLE A-3. Generic Construction Schedule for Interest During Construction (IDC)

Year

1

2

3

4

5

6

7

\begin{tabular}{|c|c|}
\hline Pe & $\frac{\text { xpended }}{\text { Substation }}$ \\
\hline 0.5 & \\
\hline 1.0 & \\
\hline 1.0 & \\
\hline 9.4 & 0.2 \\
\hline 11.7 & 8.6 \\
\hline 58.0 & 67.5 \\
\hline 18.4 & 23.7 \\
\hline 100.0 & 100.0 \\
\hline
\end{tabular}

TABLE A-4. Unit Value of Losses

$\begin{array}{lr}\text { Energy } & 42 \mathrm{mills} / \mathrm{kWh} \\ \text { Capacity } & \$ 54 / \mathrm{kW}\end{array}$

These values are based on the BPA Time-Differentiated Long-Run Incremental cost (TDLRIC) analysis (March 1982).

If $L_{0} F=$ Loss factor, then the annual cost of losses, in dollars per peak $\mathrm{kW}, C_{L}$, is found as:

$C_{L}=0.042(8760)\left(L_{0} F\right)+54\left(1-L_{0} F\right)$ 
PNL-4685

UC -80

DISTRIBUTION

No. of

Copies

OFFSITE:

W. F. Savage, Chief Advanced Concepts Evaluation Branch

Mai1 Stop F-309

Washington, DC 20545

Arlee Holm

Bonneville Power Administration P. 0. Box 3621

Portland, Oregon 97208

Ricky Poon

Bonneville Power Administration

P. 0. Box 3621

Portland, Oregon 97208

Brian Silverstein

Bonneville Power Administration

P. 0. Box 3621

Portland, Oregon 97208

Library

Bonneville Power Administration

P. 0. Box 3621

Portland, Oregon 97208

$3 \quad$ Files

Bonneville Power Administration

P. 0. Box 3621

Portland, Oregon 97208

27 DOE Technical Information Center
No. of

Copies

ONSITE:

DOE Richland Operations Office

H. E. Ransom

K. W. Bracken

0 . J. Elgert

F. R. Standerfer

UNC Nuclear Industries

W. R. McSpadden

R. L. Richardson

Rockwel1 Hanford Operations

C. M. Salina

34 Pacific Northwest Laboratory

F. W. Albaugh

C. E. Diemond - consultant

W. J. Dowis - consultant

S. J. Farmer

H. Harty (20)

A. M. Platt

W. D. Richmond

L. D. Williams

Publishing Coordination (2)

Technical Information (5) 
